\title{
Another brick in the wall: population dynamics of a symbiotic species of Oxydromus (Annelida, Hesionidae), described as new based on morphometry
}

\author{
Daniel Martin ${ }^{1, *}$, Miguel A. Meca ${ }^{1}$, João Gil ${ }^{1}$, Pilar Drake $^{2} \&$ Arne Nygren ${ }^{3}$ \\ ${ }^{1}$ Centre d'Estudis Avançats de Blanes (CEAB-CSIC) - Carrer d'Accés a la Cala Sant Francesc 14. 17300 Blanes, \\ Girona, Catalunya, Spain \\ ${ }_{2}^{2}$ Instituto de Ciencias Marinas de Andalucía (ICMAN-CSIC), Avenida República Saharaui 2, Puerto Real 11519, \\ Cádiz, Spain \\ ${ }^{3}$ Sjöfartsmuseet Akvariet, Karl Johansgatan 1-3, 41459, Göteborg, Sweden \\ ${ }^{1}$ E-mail:dani@ceab.csic.es
}

Key words: Bivalvia, Cádiz Bay, Hesionidae, Iberian Peninsula, NE Atlantic Oxydromus, symbiosis, Tellinidae

urn:Isid:zoobank.org:pub: D97B28C0-4BE9-4C1E-93F8-BD78F994A8D1

\begin{abstract}
Oxydromus humesi is an annelid polychaete living as a strict bivalve endosymbiont (likely parasitic) of Tellina nymphalis in Congolese mangrove swamps and of Scrobicularia plana and Macomopsis pellucida in Iberian saltmarshes. The Congolese and Iberian polychaete populations were previously considered as belonging to the same species, the latter showing regular distribution, intra-specific aggressive behaviour, and complex hostentering behaviour. The fresh Iberian samples enabled us to undertake consistent morphometric analyses, as well as to further analyse the characteristics of the association and the population dynamics of the Iberian population hosted by S. plana. Among the morphological differences between the Congolese and Iberian specimens, leading to the description of the latter as Oxydromus okupa sp. nov., the most important are: 1) longer cephalic appendages, 2) greater distance between the eyes, 3) larger dorsal cirrostyle in relation to the corresponding dorsal lobe and cirrophore. Moreover, dorsal and ventral lobes are similar in length, with the tip of the former reaching the tip of the latter in O. okupa sp. nov., while the dorsal lobe is much shorter than the ventral one in $O$. humesi. Mature adults of $O$. okupa sp. nov. occurred during the whole study period, with a higher percentage of ripe females in spring and, particularly, in summer. Numerous host specimens showed the symbiont's most preferred shell length (>26 - $36 \mathrm{~mm}$ ). However, the prevalence was very low (usually $<5 \%$ ) and showed a clear seasonal pattern, being lower during spring/summer. This suggests that males are able to leave their hosts during this period, most likely to improve fertilization by directly entering or approaching a host occupied by a ripe female, while females usually remain inside. Based on the new results, the current knowledge of symbiotic Hesionidae and their relationships with invertebrate hosts is updated and discussed.
\end{abstract}

\section{Contents}

\begin{tabular}{|c|}
\hline ..................... \\
\hline Morphometry \\
\hline Population size-structure \\
\hline Infestation characteristics .. \\
\hline 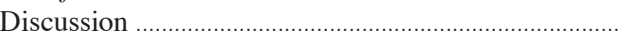 \\
\hline Morphometry and taxonomy \\
\hline Infestation characteristics ..... \\
\hline 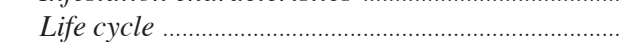 \\
\hline $\begin{array}{l}\text { Relationships between life-cycle and infestation } \\
\text { characteristics }\end{array}$ \\
\hline Current knowledge on hesionid symbionts ......................... \\
\hline Acknowledgements \\
\hline References ................... \\
\hline Appendix ......... \\
\hline
\end{tabular}

\section{Introduction}

The Hesionidae is a well-known family of polychaetes whose representatives are most often free-living in shallow waters, although some occur in the deep-sea (Summers et al., 2015) and some lives as symbionts of other invertebrates (Martin and Britayev, 1998; Miller and Wolf, 2008; De Assis et al., 2012; Martin et al., 2012, 2015; Britayev et al., 2013; Chim et al., 2013).

Oxydromus humesi (Pettibone, 1961), which is one of these symbiotic hesionids, has been reported as a strict bivalve-associate that is hosted by Tellina nymphalis Lamarck, 1818 in Loango (Congo mangrove swamps) and by Scrobicularia plana (Da Costa, 1778) and Macomopsis pellucida (Spengler, 1798) (reported as Macoma cumana (O.G. Costa, 1830)) in Cádiz Bay, Iberian Peninsula (Pettibone, 1961; Martin et al., 2012, 2015). The Iberian hosts show similar morphologies and modes of life. However, in Cádiz Bay, M. pellucida 


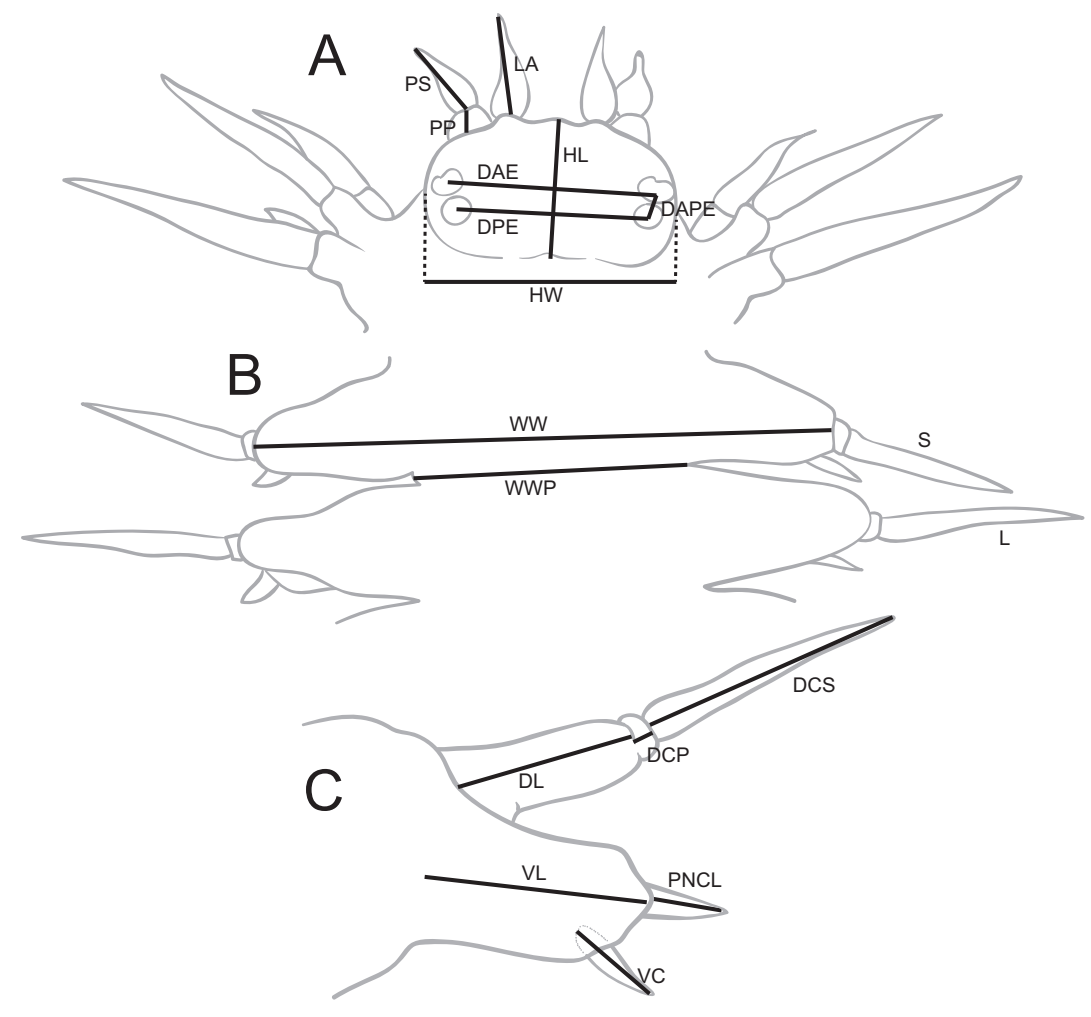

Fig. 1. Oxydromus okupa sp. nov. Schemes of anterior end (a), two midbody segments (b) and one mid-body parapodia (c), showing the measurements used in the morphometric analyses. WW: worm width with parapodia $(\mu \mathrm{m})$; WWP: worm width without parapodia $(\mu \mathrm{m})$; HW: head width $(\mu \mathrm{m})$; HL: head length $(\mu \mathrm{m})$; LA: length of lateral antenna $(\mu \mathrm{m})$; PP: length of palpophore $(\mu \mathrm{m})$; PS: length of palpostyle $(\mu \mathrm{m})$; DAE: distance between anterior eyes $(\mu \mathrm{m})$; DPE: distance between posterior eyes $(\mu \mathrm{m})$; DAPE: distance between anterior and posterior eyes $(\mu \mathrm{m})$; DL: length of dorsal lobe $(\mu \mathrm{m})$ : DCP: length of dorsal cirrophore $(\mu \mathrm{m})$; DCS: length of dorsal cirrostyle $(\mu \mathrm{m})$; PNCL: length of posterior neurochaetal lobe $(\mu \mathrm{m})$; VL: ventral lobe; VC: length of ventral cirri $(\mu \mathrm{m})$; L: long cirrostyle; $S$ : short cirrostyle. occurs mainly in the subtidal (E. Pascual, pers. observ.), whilst it is very rare in the intertidal (Subida et al., 2013). In turn, S. plana occurs in intertidal saltmarshes (like Río San Pedro), where it shows very high abundances (Subida et al., 2011; Drake et al., 2014).

Based on occasional sampling of mainly S. plana associates, it has been inferred that the association apparently affects negatively the metabolism of the host (and so it is considered to be closer to a parasitism), that infestations did not occur in hosts measuring less than $20 \mathrm{~mm}$ in shell length, that all symbionts seem to be adults (which are not sexually dimorphic), and that there are no relationships between worm's size and shell length (Martin et al., 2012, 2015). However, nothing is known of the seasonal characteristics of the association, as well as of the life cycle of the symbiont. Also, when re-describing O. humesi, Martin et al. (2015) discussed the possibility of having different species at the two known locations due to an hypothetical biogeographic isolation of the respective populations. The fact that no fresh specimens were available from the Congolese population (i.e. the original specimens were formalin-fixed) prevented a molecular approach. Morphologically, animals of the two known populations ap- peared to be indistinguishable and a preliminary comparison of chaetal morphology and appendage measurements based on the available specimens was therefore inconclusive (Martin et al., 2015), which lead us to undertake a more robust study based on morphometry.

Therefore, the following questions were addressed: Were hosts $<20 \mathrm{~mm}$ infested during the seasonal cycle? Did the symbionts prefer any host size among those $>20 \mathrm{~mm}$ ? Were the prevalence and intensity of infestation constant along time? Had the symbiont a seasonal trend in reproductive traits or size-class structure? These observations were compared with the few available data on symbionts infesting $M$. pellucida. Based on the new results, the current knowledge on the symbiotic relationships involving hesionid polychaetes worldwide is summarized and discussed.

\section{Material and Methods}

Collection details and sampling were explained by Martin et al. (2015). Specimens of the host bivalves were collected: monthly, from April 2011 to May 2012 and in January 2013, at Río San Pedro, 36³1'56.28”, 
6¹2'53.28” (S.plana); in January 2013 at Río San Pedro mouth, 36³1'47.28”, 6¹4'52.80" (M. pellucida). The specimens of S. plana from May 2011 were damaged during sampling. All applicable international, national, and/or institutional guidelines for the care and use of animals were followed. Possible non-biotic influences in the observed patterns could not be determined because no environmental data were recorded during the study period.

In the laboratory, the collected specimens of $S$. pla$n a$ and M.pellucida were opened to estimate the infestation intensity and prevalence. All obtained worms, and the bivalves harbouring them, were counted. The longest shell diameter of the hosts was measured (length, in $\mathrm{mm}$ ) using callipers. Samples of S. plana (i.e. 100 to 300 specimens) were collected monthly and measured (independently of the presence of the symbiont) to define the seasonal size structure of the host population.

The width (in $\mu \mathrm{m}$ ) of the tenth segment (parapodia included) was used as a proxy for symbiont size (WW). WW was measured under a Nikon SMZ645 stereomicroscope equipped with a micrometric ocular. Ripe females were identified by the presence of intracoelomic oocytes, which were usually visible through the body wall. In preserved specimens, the worm tissues become more opaque than in living ones, which usually hindered observation of the oocytes. Their presence was confirmed by placing the worms in a Petri dish and then cutting their body wall and applying a gentle pressure with the forceps so that present oocytes would spill from the coelomic cavity for observation. Digital images were taken with a CMEX camera, linked to a Zeiss Stemi 2000-c, stereomicroscope, using the ImageFocus 4.0 software by Euromex.

The sizes of the Iberian symbionts and their hosts were used to estimate their monthly size-class frequencies. The frequency of infested bivalves and that of the whole population was estimated separately and then expressed as percentages for comparison. The worm/ host size and the ripe females/prevalence relationships were assessed by correlation analyses, while differences in percentage of females and prevalence during warm (i.e. March to September) and cold (i.e. October to February) periods were assessed by one-way Analysis of Variance (one-way ANOVA).

For morphometric purposes, preserved specimens of the Congolese population were kindly loaned by the United States National Museum of the Smithsonian Institution (USNM). Twenty-five specimens from the Iberian population, representative of all available sizes, were selected for the analyses, while for the Congolese population, 25 specimens were selected on the basis of the quality of the available specimens (as all of them were similar in size). The following characters were selected and measured (Fig. 1): WW, worm width without parapodia (WWP, $\mu \mathrm{m}$ ), worm length (WL, $\mu \mathrm{m}$ ), number of segments (NS), head width (HW, $\mu \mathrm{m})$, head length (HL, $\mu \mathrm{m})$, length of lateral antenna (LA, $\mu \mathrm{m}$ ), length of palpophore (PP, $\mu \mathrm{m}$ ), length of palpostyle (PS, $\mu \mathrm{m}$ ), distance between anterior eyes (DAE, $\mu \mathrm{m}$ ), distance between posterior eyes (DPE, $\mu \mathrm{m}$ ), distance between anterior and posterior eyes (DAPE, $\mu \mathrm{m}$ ), length of dorsal lobe (DL, $\mu \mathrm{m}$ ), length of dorsal cirrophore (DCP, $\mu \mathrm{m})$, length of dorsal cirrostyle (DCS, $\mu \mathrm{m}$ ), length of posterior neurochaetal lobe (PNCL, $\mu \mathrm{m}$ ), and length of ventral cirri (VC, $\mu \mathrm{m}$ ) (measured at the $10^{\text {th }}$ parapodia level). As cirrostyles alternate short and long along the body (Martin et al., 2015), the measurements were recorded for two parapodia (from chaetiger 10 to 30 , depending on the specimen) bearing long and short cirrostyles, respectively, and indicated by adding $\mathrm{L}$ and $\mathrm{S}$ to the end of the acronym (e.g. "DCSL" and "DCSS" meaning dorsal cirrostyle from parapodia having long and short cirrostyles, respectively). Special care was addressed to avoid measurements on damaged appendages. The eyespot diameter, which is highly variable among the specimens of the two species (probably as a result to different individual responses to fixation) was not considered a valid taxonomic character and was not used in the statistical analyses. This also led us to measure all characters based on the eyes at the centre of each eyespot (Fig. 1). WWP, WL and NS were measured as WW, while the remaining characters were measured under a Motic BA210 binocular microscope equipped with a TOUPCAM ${ }^{\mathrm{TM}}$ U3CMOS digital camera, managed through the ToupView 3.7 software.

The inter-population differences were analysed for three different datasets: 1) raw data (direct measurements), 2) size-independent data; 3) taxonomically relevant character proportions (i.e., WL/WW, NS/WW, WWP/WW, DCPL/DLL, DCSL/DLL, DCSL/DCPL, VCL/PNCLL, DCPS/DLS, DCSS/DLS, DCSS/DCPS, VCS/PNCLS, HL/HW, LA/HL, PP/HL, PS/HL, PS/PP, DAE/HW, DPE/HW, DAPE/HL, DAE/DPE). Size-dependency of both measured characters and character proportions was assessed by Pearson correlation. Sizeindependent measurements were used without transformation, while size-dependent ones were divided by worm size (WW). The inter-population differences for the averaged measurements were estimated by one-way ANOVAs. Since multiple F-tests were carried out within each data set, the level of statistical significance was set 

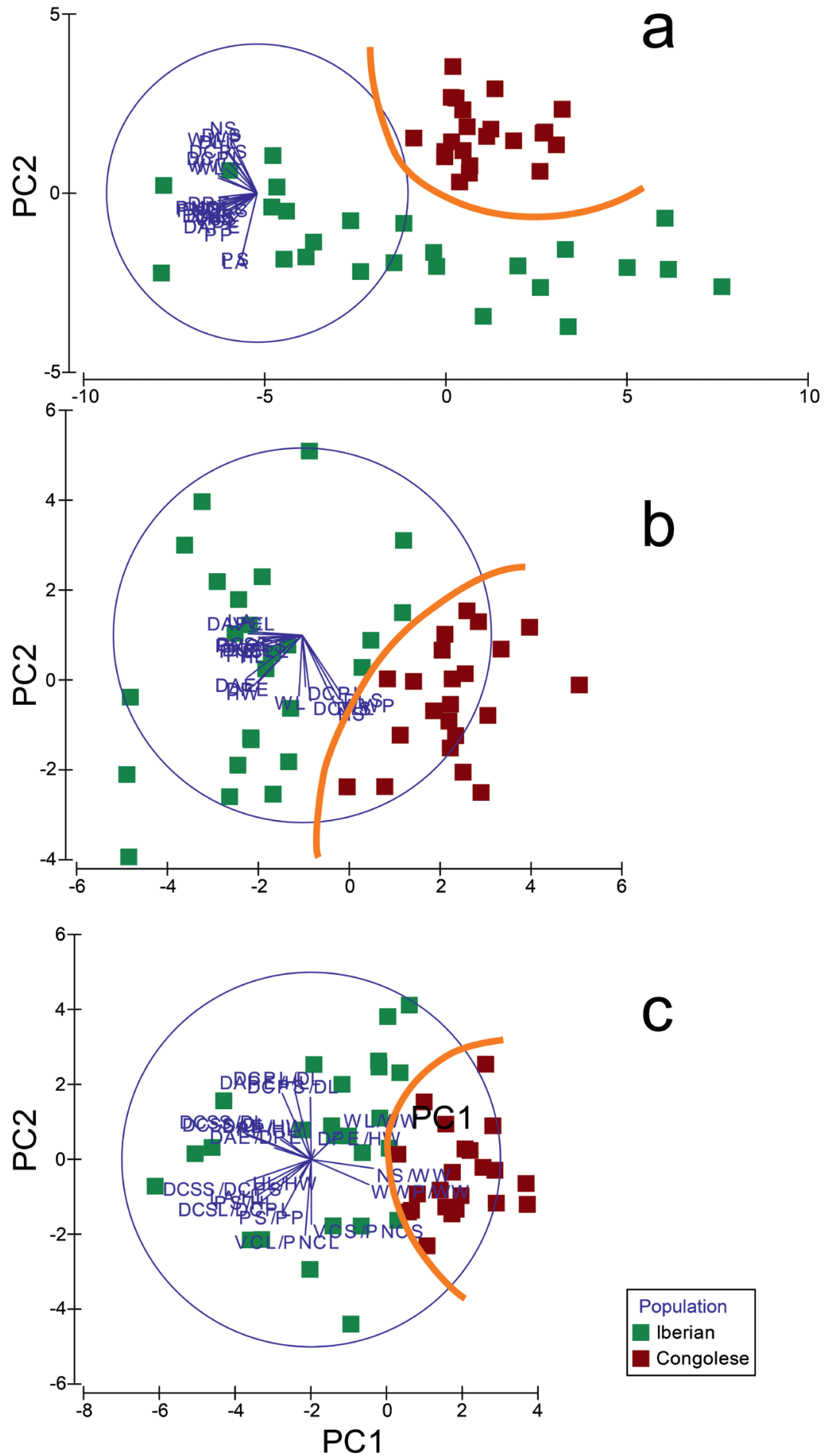

Fig. 2. Principal Component Analyses plots. a. Based on raw data. b. Based on size independent data. c. Based on measurement proportions.

at $p<0.05$ and adjusted according to false discovery rate procedure (Benjamini and Hochberg, 1995). To avoid biases due to size differences, the description of the new species was based on the size-independent data as well as on the character proportions.

All character sets (i.e., raw data, size-independent 
Table 1. Relationships with worm size (as body width with parapodia) in Oxydromus okupa sp. nov., with bold characters indicating significant differences. A. Morphometric measurements. B. Taxonomically relevant proportions. Measurement abbreviations as in Fig. 1. Coeff: Pearson correlation coefficient; p: significance level.

\begin{tabular}{|c|c|c|c|c|c|c|c|c|c|}
\hline \multirow{2}{*}{$\begin{array}{l}\text { A. } \\
\text { Measurements }\end{array}$} & \multicolumn{2}{|c|}{ Iberian } & \multicolumn{2}{|c|}{ Congolese } & \multirow{2}{*}{$\begin{array}{l}\text { B. } \\
\text { Proportions }\end{array}$} & \multicolumn{2}{|l|}{ Iberian } & \multicolumn{2}{|c|}{ Congolese } \\
\hline & Coeff & $\mathbf{p}$ & Coeff & $\mathbf{p}$ & & Coeff & $\mathbf{p}$ & Coeff & $\mathbf{p}$ \\
\hline WL & 0.873 & $<0.0001$ & 0.784 & $<0.0001$ & WL/WW & 0.608 & 0.001 & 0.369 & 0.091 \\
\hline NS & 0.749 & $<0.0001$ & 0.529 & 0.011 & NS/WW & 0.056 & 0.789 & -0.542 & 0.009 \\
\hline WWP & 0.846 & $<0.0001$ & 0.600 & 0.003 & WWP/WW & 0.219 & 0.293 & -0.200 & 0.373 \\
\hline DLL & 0.863 & $<0.0001$ & 0.289 & 0.193 & DCPL/DLL & 0.104 & 0.619 & 0.158 & 0.483 \\
\hline DCPL & 0.777 & $<0.0001$ & 0.341 & 0.121 & DSCL/DLL & -0.476 & 0.016 & 0.144 & 0.52 \\
\hline DCSL & 0.835 & $<0.0001$ & 0.365 & 0.094 & DSCL/DCPL & -0.489 & 0.013 & -0.036 & 0.872 \\
\hline PNCLL & 0.780 & $<0.0001$ & 0.211 & 0.346 & VCL/PNCL & -0.170 & 0.418 & 0.183 & 0.416 \\
\hline VCL & 0.625 & 0.001 & 0.597 & 0.003 & DCPS/DLS & 0.189 & 0.366 & -0.100 & 0.65 \\
\hline DLS & 0.835 & $<0.0001$ & 0.504 & 0.017 & DSCS/DLS & -0.478 & 0.016 & 0.003 & 0.989 \\
\hline DCPS & 0.716 & $<0.0001$ & 0.164 & 0.466 & DSCL/DCPL & -0.438 & 0.028 & 0.062 & 0.783 \\
\hline DCSS & 0.796 & $<0.0001$ & 0.384 & 0.078 & VCS/PNCS & -0.066 & 0.755 & 0.207 & 0.356 \\
\hline PNCLS & 0.713 & $<0.0001$ & 0.223 & 0.319 & HL/HW & -0.564 & 0.003 & 0.103 & 0.647 \\
\hline VCS & 0.693 & 0.000 & 0.574 & 0.005 & LA/HL & -0.379 & 0.062 & 0.077 & 0.732 \\
\hline HW & 0.896 & $<0.0001$ & 0.239 & 0.283 & PP/HL & 0.151 & 0.472 & -0.067 & 0.767 \\
\hline HL & 0.646 & 0.000 & 0.319 & 0.147 & PS/HL & -0.472 & 0.017 & -0.363 & 0.096 \\
\hline LA & 0.099 & 0.637 & 0.215 & 0.336 & $\mathrm{PS} / \mathrm{PP}$ & -0.498 & 0.011 & -0.256 & 0.250 \\
\hline PP & 0.654 & 0.000 & 0.278 & 0.210 & DAE/HW & -0.212 & 0.310 & -0.364 & 0.096 \\
\hline PS & 0.086 & 0.684 & -0.120 & 0.595 & DPE/HW & -0.106 & 0.614 & -0.274 & 0.218 \\
\hline DAE & 0.860 & $<0.0001$ & 0.090 & 0.691 & DAPE/HL & 0.729 & $<0.0001$ & 0.080 & 0.722 \\
\hline DPE & 0.878 & $<0.0001$ & 0.099 & 0.663 & DAE/DPE & -0.100 & 0.636 & 0.003 & 0.990 \\
\hline DAPE & 0.809 & $<0.0001$ & 0.337 & 0.126 & & & & & \\
\hline
\end{tabular}

data, proportions) were analysed by Principal Component Analysis (PCA) based on normalised data. The significance of the inter-population differences was explored by one-way analysis of similarity (ANOSIM) based on Euclidean distance resemblance matrices, while the contribution of each measured character to the distance within and between the two populations was assessed by the Similarity Percentages analysis (SIMPER) based on Euclidean distance. Forward stepwise discriminant analyses (FSDA) were used to obtain discriminant functions for the two populations under study, using the three datasets and assuming equal intra-population covariance matrices and threshold significance levels of 0.05 both to include and to remove variables. The similarity of the intra-population covariance matrices was assessed by the Box test (based on an asymptotic approach to the Fisher's F index) and the differences between population-averaged vectors were assessed by the Rao approach to the Wilks' Lambda test. The classification matrices were built by considering the sensitivity percentage (i.e. well classified positive events) as belonging to the Iberian population, and the specificity percentage (i.e., well classified negative events) as belonging to the Congolese population. Furthermore, to determine the probability that one of the observed specimens would effectively belong to one of the two populations, we also performed a cross-validation in which each observation was removed from the original matrix and the model and the forecast successively estimated, allowing a better adjust to the model (Huberty, 1994).

Pearson correlation analyses, one-way ANOVAs and discriminant analyses were performed with the XLSTAT software (2015.5.01.23039, copyright by Addinsoft 1995-2016). All remaining analyses were conducted using the PRIMER software, version 6.1.11, copyright by PRIMER-E Ltd. 2008 (Clarke and Warwick, 2001; Clarke and Gorley, 2006). 


\begin{tabular}{llllll}
\hline Iberian & Av.Value & Av.Sq.Dist & Sq.Dist/SD & Contrib\% & Cum.\% \\
\hline PS & 0.597 & 0.672 & 0.51 & 2.30 & 2.30 \\
LA & 0.648 & 0.68 & 0.41 & 2.33 & 4.63 \\
PP & 0.587 & 0.97 & 0.52 & 3.32 & 7.95 \\
DAPE & 0.522 & 1.09 & 0.49 & 3.73 & 11.68 \\
DCSS & 0.397 & 1.1 & 0.48 & 3.76 & 15.44 \\
DCSL & 0.324 & 1.18 & 0.50 & 4.05 & 19.49 \\
DLS & -0.424 & 1.21 & 0.47 & 4.14 & 23.63 \\
HL & 0.267 & 1.26 & 0.49 & 4.31 & 27.94 \\
VCS & 0.383 & 1.35 & 0.53 & 4.62 & 32.56 \\
DAE & 0.376 & 1.39 & 0.50 & 4.76 & 37.32 \\
\hline
\end{tabular}

Congolese

\begin{tabular}{lrllll}
\hline NS & 0.46 & 0.13 & 0.43 & 1.83 & 1.83 \\
WL & -0.201 & 0.168 & 0.45 & 2.36 & 4.19 \\
PP & -0.667 & 0.206 & 0.51 & 2.91 & 7.10 \\
VCL & -0.386 & 0.212 & 0.53 & 2.99 & 10.08 \\
WW & $-8.21 E-2$ & 0.214 & 0.52 & 3.01 & 13.09 \\
DPE & -0.283 & 0.242 & 0.47 & 3.41 & 16.50 \\
DAE & -0.427 & 0.242 & 0.47 & 3.41 & 19.91 \\
WWP & 0.319 & 0.242 & 0.53 & 3.41 & 23.32 \\
PNCLL & -0.377 & 0.245 & 0.46 & 3.45 & 26.77 \\
DAPE & -0.593 & 0.255 & 0.51 & 3.58 & 30.35 \\
\hline
\end{tabular}

\begin{tabular}{lccclcr}
\hline & $\begin{array}{l}\text { Iberian } \\
\text { Av.Value }\end{array}$ & $\begin{array}{l}\text { Congolese } \\
\text { Av.Value }\end{array}$ & Av.Sq.Dist & Sq.Dist/SD & Contrib\% & Cum.\% \\
\hline LA & 0.648 & -0.737 & 2.9 & 0.88 & 5.96 & 5.96 \\
PS & 0.597 & -0.678 & 2.76 & 0.80 & 5.68 & 11.64 \\
PP & 0.587 & -0.667 & 2.7 & 0.95 & 5.55 & 17.18 \\
DAPE & 0.522 & -0.593 & 2.53 & 0.89 & 5.20 & 22.38 \\
DLS & -0.424 & 0.482 & 2.32 & 0.78 & 4.76 & 27.15 \\
DCSS & 0.397 & -0.451 & 2.28 & 0.95 & 4.69 & 31.84 \\
NS & -0.405 & 0.46 & 2.25 & 0.73 & 4.63 & 36.47 \\
VCS & 0.383 & -0.435 & 2.23 & 0.89 & 4.58 & 41.04 \\
DAE & 0.376 & -0.427 & 2.21 & 0.97 & 4.54 & 45.59 \\
DCSL & 0.324 & -0.368 & 2.16 & 0.88 & 4.44 & 50.03 \\
\hline
\end{tabular}

Table 2. List of the ten most contributing raw measurements to the intra-population similarities and inter-population dissimilarity based on the SIMPER analyses. Measurement abbreviations as in Fig. 1. Av.Value: Average value; Av.Sq.Dist: average square distance; Sq.Dist/SD: square distance divided by standard deviation; Contrib\%: percentage of contribution; Cum.\%: cumulative percentage of contribution.

\section{Results}

\section{Morphometry}

Raw data. The PCA based on raw data shows a strong size-dependency of most characters, with the first axis (Eigenvalue $=12.0)$ explaining $54.6 \%$ of the variation and the second one (Eigenvalue $=3.52$ ) only $16.0 \%$ (Fig. 2A). All characters of the Iberian population were size-dependent (except LA and PS), while the only size-dependent characters in the Congolese population were WL, NS, WWP, VCL, DLS and VCS (Table 1A). The size-relationship in the PCA plot was also more evident for the Iberian population, whose specimens showed a wider size-range representativeness than the
Congolese ones. Nevertheless, the two populations clearly form separate groups in the PCA plot, and turned to be significantly different (ANOSIM, Global $\mathrm{R}=0.435$, significance level $=0.1 \%$ ).

The intra-population average distances for the Iberian and Congolese worms were $29.9 \%$ and $7.10 \%$, respectively, whilst the inter-population dissimilarity was 48.67\%. PS, LA and PP, and NS, WL and PP most contributed to the Iberian and Congolese intra-population similarity, respectively, whilst LA, PS and PP most contributed to the inter-population dissimilarity (SIMPER, Table 2).

All averaged character measurements showing significant differences were higher in the Iberian than in the Congolese population, except for NS and DLS, with 
Table 3. Comparative table of the raw morphometric measurements $(\mu \mathrm{m})$ in the Iberian and Congolese populations. Differences expressed as percentages, with bold characters indicating significant differences (according to Benjamini \& Hochberg, 1995) that may be higher (normal text) or lower (italics) in the Iberian than in the Congolese population, respectively. Measurement abbreviations as in Fig. 1. Min: minimum; Max: maximum; Mean: average \pm standard deviation; F: Fisher's F index; p: significance level.

\begin{tabular}{|c|c|c|c|c|c|c|c|c|c|}
\hline & \multicolumn{3}{|c|}{ Iberian Population } & \multicolumn{3}{|c|}{ Congolese Population } & \multicolumn{2}{|l|}{ ANOVA } & Difference \\
\hline & Min & Max & Mean & Min & $\operatorname{Max}$ & Mean & $\mathbf{F}$ & $p$ & $\%$ \\
\hline WW & 1875.00 & 3443.00 & $2633.27 \pm 497.83$ & 2250.00 & 2866.67 & $2536.67 \pm 194.86$ & 0.816 & 0.371 & 1.9 \\
\hline WL & 8000.00 & 33435.90 & $20819.19 \pm 7604.17$ & 15139.24 & 24820.51 & $18611.64 \pm 2389.06$ & 1.816 & 0.184 & 5.6 \\
\hline NS & 29.00 & 76.00 & $56.58 \pm 14.11$ & 60.00 & 78.00 & $66.77 \pm 4.24$ & 11.303 & 0.002 & 8.3 \\
\hline WWP & 604.17 & 1525.00 & $1055.33 \pm 263.12$ & 925.00 & 1375.00 & $1170.00 \pm 119.02$ & 3.941 & 0.053 & 5.2 \\
\hline DLL & 154.14 & 492.73 & $337.78 \pm 100.82$ & 316.78 & 473.84 & $378.92 \pm 39.21$ & 3.615 & 0.063 & 5.7 \\
\hline DCPL & 29.78 & 136.99 & $66.94 \pm 25.25$ & 36.04 & 84.25 & $65.63 \pm 13.55$ & 0.052 & 0.820 & 1.0 \\
\hline DCSL & 398.45 & 913.87 & $663.81 \pm 136.56$ & 418.99 & 869.06 & $565.64 \pm 94.49$ & 8.737 & 0.005 & 8.0 \\
\hline PNCLL & 113.96 & 315.28 & $212.31 \pm 65.01$ & 90.26 & 229.40 & $168.23 \pm 31.26$ & 9.334 & 0.004 & 11.6 \\
\hline VCL & 155.63 & 387.73 & $259.18 \pm 69.38$ & 177.06 & 258.60 & $216.29 \pm 27.29$ & 8.271 & 0.006 & 9.0 \\
\hline DLS & 125.32 & 517.34 & $328.61 \pm 95.41$ & 331.03 & 502.24 & $406.43 \pm 49.45$ & 13.108 & 0.001 & 10.6 \\
\hline DCPS & 26.45 & 118.90 & $62.82 \pm 25.11$ & 37.83 & 109.78 & $64.16 \pm 15.52$ & 0.051 & 0.822 & 1.1 \\
\hline DCSS & 344.68 & 801.26 & $603.00 \pm 122.10$ & 366.63 & 705.07 & $493.54 \pm 85.87$ & 13.442 & 0.001 & 10.0 \\
\hline PNCLS & 85.78 & 322.40 & $208.02 \pm 63.89$ & 90.84 & 222.50 & $164.20 \pm 31.51$ & 9.458 & 0.003 & 11.8 \\
\hline VCS & 158.33 & 374.15 & $262.02 \pm 64.97$ & 165.31 & 270.01 & $216.46 \pm 28.19$ & 8.271 & 0.006 & 9.5 \\
\hline HW & 411.57 & 785.31 & $614.68 \pm 108.05$ & 448.16 & 654.12 & $550.64 \pm 49.60$ & 7.253 & 0.010 & 5.5 \\
\hline $\mathrm{HL}$ & 236.14 & 402.91 & $331.47 \pm 47.24$ & 231.31 & 371.43 & $306.69 \pm 30.01$ & 4.900 & 0.032 & 3.9 \\
\hline LA & 133.55 & 360.21 & $235.76 \pm 45.30$ & 105.40 & 220.68 & $159.05 \pm 31.87$ & 47.964 & $<0.0001$ & 19.4 \\
\hline PP & 71.72 & 136.80 & $101.67 \pm 18.56$ & 62.44 & 93.26 & $77.28 \pm 8.32$ & 35.945 & $<0.0001$ & 13.6 \\
\hline PS & 130.57 & 223.77 & $168.91 \pm 27.77$ & 61.88 & 165.44 & $126.68 \pm 23.65$ & 33.523 & $<0.0001$ & 14.3 \\
\hline DAE & 322.40 & 621.90 & $503.43 \pm 85.83$ & 390.00 & 524.90 & $442.24 \pm 35.70$ & 10.831 & 0.002 & 6.5 \\
\hline DPE & 287.10 & 604.40 & $452.76 \pm 79.49$ & 370.30 & 493.10 & $416.02 \pm 30.37$ & 4.663 & 0.036 & 4.2 \\
\hline DAPE & 46.02 & 118.40 & $83.49 \pm 18.41$ & 50.27 & 79.48 & $64.29 \pm 8.61$ & 22.321 & $<0.0001$ & 13.0 \\
\hline
\end{tabular}

\begin{tabular}{lrrrrrr}
\hline Raw data & F & Lambda & p & Coeff. & Congo & Iberian \\
\hline Intercept & & & & & -21.601 & -41.824 \\
DLS & 12.366 & 0.784 & 0.001 & -1.417 & 0.022 & -0.062 \\
PP & 31.334 & 0.590 & $<0.0001$ & 0.916 & 0.162 & 0.451 \\
PNCLL & 6.914 & 0.867 & 0.012 & 0.716 & 0.042 & 0.108 \\
LA & 44.014 & 0.506 & $<0.0001$ & 0.548 & 0.080 & 0.144 \\
\hline
\end{tabular}

\section{Size independent}

\begin{tabular}{lrrrrrr}
\hline Intercept & & & & & -83.702 & -92.545 \\
WL & 1.365 & 0.971 & 0.249 & 1.023 & -3.634 & 0.633 \\
NS & 29.795 & 0.602 & $<0.0001$ & -0.967 & 3471.027 & 1471.413 \\
DLS & 36.121 & 0.555 & $<0.0001$ & -0.832 & 254.506 & 7.696 \\
PP & 37.264 & 0.547 & $<0.0001$ & 0.754 & 537.571 & 1448.983 \\
PNCLL & 9.920 & 0.819 & 0.003 & 0.471 & 417.520 & 630.082 \\
LA & 44.014 & 0.506 & $<0.0001$ & 0.400 & 0.107 & 0.167 \\
\hline
\end{tabular}

\section{Proportions}

\begin{tabular}{lrrrrrr}
\hline Intercept & & & & & -397.626 & -482.539 \\
WL/WW & 1.365 & 0.971 & 0.249 & 1.473 & 9.379 & 14.975 \\
NS/WW & 29.795 & 0.602 & $<0.0001$ & 1.120 & 141.420 & -1968.232 \\
DCSS/DLS & 48.629 & 0.481 & $<0.0001$ & 0.880 & 39.606 & 53.963 \\
PS/HL & 20.926 & 0.683 & $<0.0001$ & 0.639 & 88.314 & 130.671 \\
DAE/DPE & 16.763 & 0.729 & 0.0002 & 0.371 & 599.499 & 646.260 \\
\hline
\end{tabular}

Table 4. Results of the discriminant analyses based on raw data, size-independent data and measurement proportions. F: Fisher's F index; Lambda: Rao approach to the Wilks' Lambda test; p: significance level; Coeff.: Standardized coefficients for the variables included in the inter-population discriminant functions, arranged in a decreasing order, according to their contribution to the inter-population discrimination; Congo, Iberian: coefficients of the selected variables in the classification functions for the Congolese and Iberian populations, respectively. Intercept: Intercept of the classification functions for each dataset. Measurement abbreviations as in Fig. 1. 


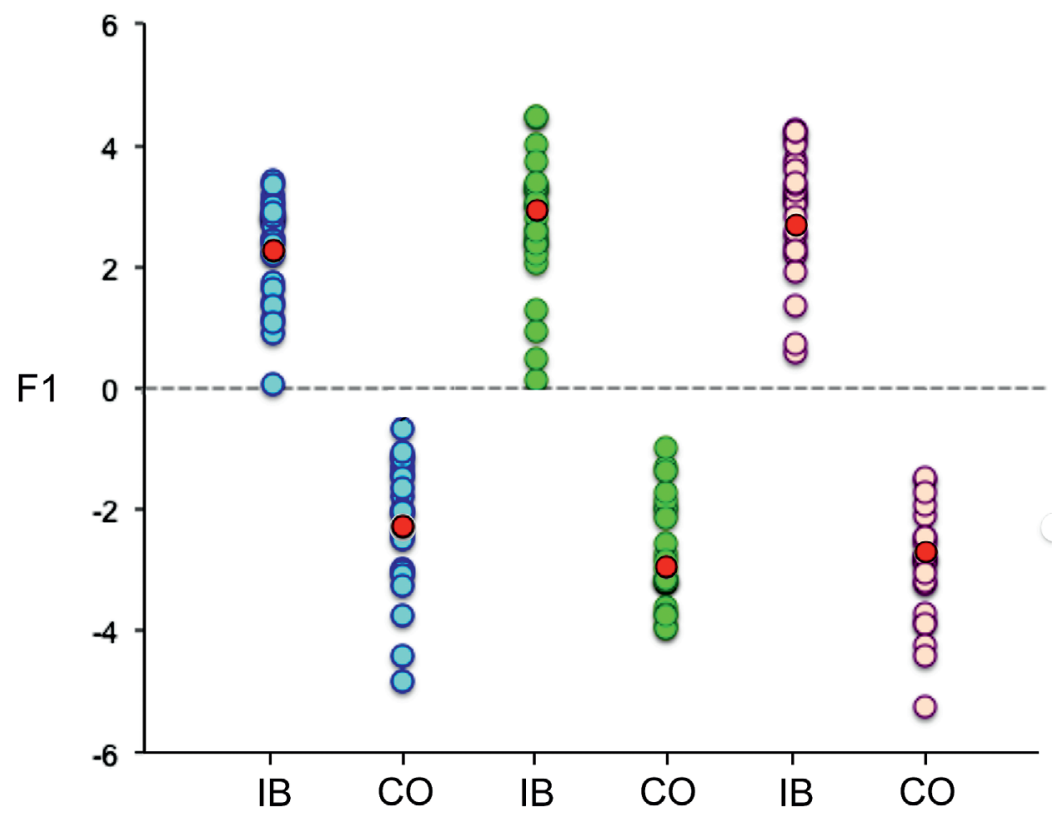

\section{Raw data Size independent Proportions Centroids}

Fig. 3. Scatterplots for individual scores and centroids of the discriminant functions obtained by the discriminant analyses carried out on the three datasets: raw data, size-independent data and measurement proportions. IB: Iberian population; CO: Congolese population. the most remarkable difference being at LA (one-way ANOVA, Table 3).

Based on raw data, the discriminant function included the variables DLS, PP, PNCLL and LA (Table 4). This function correctly classified the $100 \%$ of individuals from both localities (Fig. 3) and the success probability in the cross validation was of $98 \%$.

Size-independent data. For the purpose of this analysis, and taking into account that the size range was well represented in the Iberian population, only LA and PS raw data were considered as size-independent (Table 1A). The PCA plot based on size-independent data revealed again two clearly different groups corresponding to the two studied populations (Fig. 2B). Despite the axes being less representative than those obtained for the raw data $($ Eigenvalues $=6.61$ and 3.49, variation explained $=$ $31.5 \%$ and $16.6 \%$, respectively for axis 1 and 2 ), the two populations were more clearly distinguishable and showed more significant differences than the raw data (ANOSIM, global $\mathrm{R}=0.539$, significance level $=0.1 \%$ ).

Based on these size-independent characters, the intra-population average distance within the Iberian and Congolese populations was $21.0 \%$ and $11.1 \%$, respectively, whilst the inter-population distance was 50.3\%. PS, DAPE and LA, and WL, NS, VCS, and PP most contributed to the Iberian and Congolese intra-population similarity, respectively, whilst the Congolese vs.
Iberian dissimilarity was mainly explained by LA, DAPE, DLS, PP, and PS (SIMPER, Table 5).

When comparing the averaged character measurements, all those showing significant differences were higher in the Iberian than in the Congolese population (particularly, LA, PS, PP and DAPE), except for NS, WWP, DLL, and DLS in particular (one-way ANOVA, Table 6).

Based on size-independent data, the discriminant function included the variables WL, NS, DLS, PP, PNCLL, and LA (Table 4). This function correctly classified the $100 \%$ of individuals from both localities (Fig. 3) and the success probability in the cross validation was $100 \%$.

Character proportions. Nine of the 20 character proportions analysed showed significant negative $(n=7)$ or positive $(n=2)$ correlations with size, indicating allometric relationships in the Iberian population, while only one was significantly negatively correlated with size in the case of the Congolese population (Table 1B).

In the PCA based on character proportions, Axes 1 (eigenvalue $=5.38)$ and 2 (eigenvalue $=3.13$ ) explained $26.9 \%$ and $15.6 \%$ of the variation, respectively. The PCA plot also highlighted a marked clustering for the individuals of the two populations under study (Fig. $2 \mathrm{C}$ ), the results being slightly less discriminant than the previous ones but equally highly significant (ANOSIM, Global $\mathrm{R}=0.421$, significance level $=0.1 \%$ ). 
Table 5. List of the ten most contributing size-independent measurements to the intra-population similarities and inter-population dissimilarity based on the SIMPER analyses. Measurement abbreviations as in Fig. 1. Av.Value: Average value; Av.Sq.Dist: average square distance; Sq.Dist/SD: square distance divided by standard deviation; Contrib\%: percentage of contribution; Cum.\%: cumulative percentage of contribution.

\begin{tabular}{|c|c|c|c|c|c|c|}
\hline Iberian & & Av.Value & Av.Sq.Dist & Sq.Dist/SD & Contrib\% & Cum.\% \\
\hline PS & & 0.597 & 0.672 & 0.51 & 3.20 & 3.20 \\
\hline DAPE & & 0.63 & 0.675 & 0.43 & 3.21 & 6.42 \\
\hline LA & & 0.648 & 0.68 & 0.41 & 3.24 & 9.66 \\
\hline DLS & & -0.616 & 0.686 & 0.44 & 3.27 & 12.92 \\
\hline DCSL & & 0.386 & 0.789 & 0.48 & 3.76 & 16.68 \\
\hline DCSS & & 0.463 & 0.801 & 0.47 & 3.82 & 20.50 \\
\hline HW & & 0.379 & 0.808 & 0.49 & 3.85 & 24.35 \\
\hline $\mathrm{PP}$ & & 0.618 & 0.829 & 0.46 & 3.95 & 28.31 \\
\hline DAE & & 0.434 & 0.886 & 0.49 & 4.22 & 32.52 \\
\hline WWP & & -0.527 & 0.977 & 0.49 & 4.66 & 37.18 \\
\hline Congolese & & Av.Value & Av.Sq.Dist & Sq.Dist/SD & Contrib\% & Cum.\% \\
\hline WL & & -0.176 & 0.175 & 0.47 & 1.58 & 1.58 \\
\hline NS & & 0.657 & 0.209 & 0.44 & 1.88 & 3.46 \\
\hline VCL & & -0.442 & 0.23 & 0.53 & 2.07 & 5.53 \\
\hline $\mathrm{PP}$ & & -0.703 & 0.27 & 0.49 & 2.43 & 7.95 \\
\hline VCS & & -0.51 & 0.32 & 0.50 & 2.87 & 10.83 \\
\hline LA & & -0.737 & 0.344 & 0.51 & 3.10 & 13.92 \\
\hline WWP & & 0.598 & 0.369 & 0.51 & 3.32 & 17.24 \\
\hline DAPE & & -0.716 & 0.41 & 0.51 & 3.68 & 20.92 \\
\hline DLS & & 0.7 & 0.441 & 0.51 & 3.97 & 24.89 \\
\hline PNCLS & & -0.438 & 0.492 & 0.53 & 4.43 & 29.32 \\
\hline Variable & $\begin{array}{l}\text { Iberian } \\
\text { Av.Value }\end{array}$ & $\begin{array}{r}\text { Congolese } \\
\text { Av.Value }\end{array}$ & Av.Sq.Dist & Sq.Dist/SD & Contrib\% & Cum.\% \\
\hline LA & 0.648 & -0.737 & 2.9 & 0.88 & 5.76 & 5.76 \\
\hline DAPE & 0.63 & -0.716 & 2.85 & 0.89 & 5.67 & 11.43 \\
\hline DLS & -0.616 & 0.7 & 2.81 & 0.81 & 5.59 & 17.02 \\
\hline $\mathrm{PP}$ & 0.618 & -0.703 & 2.8 & 0.87 & 5.56 & 22.58 \\
\hline PS & 0.597 & -0.678 & 2.76 & 0.80 & 5.49 & 28.08 \\
\hline NS & -0.578 & 0.657 & 2.67 & 0.81 & 5.32 & 33.39 \\
\hline WWP & -0.527 & 0.598 & 2.56 & 0.84 & 5.08 & 38.47 \\
\hline DCSS & 0.463 & -0.526 & 2.44 & 0.85 & 4.86 & 43.33 \\
\hline DAE & 0.434 & -0.493 & 2.38 & 0.80 & 4.73 & 48.05 \\
\hline VCS & 0.449 & -0.51 & 2.36 & 0.78 & 4.70 & 52.75 \\
\hline
\end{tabular}

The average intra-population distance for the Iberian and Congolese populations were $21.4 \%$ and $11.1 \%$, respectively, whilst the average inter-population distance was $46.0 \%$. DAPE/HL, DCSS/DLS, and LA/HL, and WL/WW, NS/WW, DCSS/DLS, and LA/LH were the most informative proportions for the intra-population similarity in Iberian and Congolese worms, respectively, whilst the intra-population dissimilarity was mainly explained by DCSL/DLL, LA/HL, NS/NW, and DAPE/ HL (SIMPER, Table 7).

All averaged character proportions showing signifi- cant differences, except for NS/WW and WWP/WW, were higher in the Iberian than in the Congolese population, most of them with differences higher than $10 \%$ and particularly higher than $20 \%$ in the case of DCSS/ DLS (one-way ANOVA, Table 8).

Based on character proportions, the discriminant function included the variables WL/WW, NS/WW, DCSS/DLS, PS/HL, and DAE/DPE (Table 4). This function correctly classified the $100 \%$ of individuals from both localities (Fig. 3) and the success probability in the cross validation was $96 \%$. 
Table 6. Comparative table of the size-independent morphometric measurements in the Iberian and Congolese populations. Differences expressed as percentages, with bold characters indicating significant differences (according to Benjamini and Hochberg, 1995) that may be higher (normal text) or lower (italics) in the Iberian than in the Congolese population. Measurement abbreviations as in Fig. 1. Min: minimum; Max: maximum; Mean: average \pm standard deviation ; F: Fisher's F index; p: significance level.

\begin{tabular}{|c|c|c|c|c|c|c|c|c|c|c|}
\hline & \multicolumn{3}{|c|}{ Iberian Population } & \multicolumn{3}{|c|}{ Congolese Population } & \multicolumn{2}{|c|}{ ANOVA } & \multicolumn{2}{|c|}{ Difference } \\
\hline & Min & $\operatorname{Max}$ & Mean & Min & $\operatorname{Max}$ & Mean & $\mathbf{F}$ & $p$ & $\%$ & \\
\hline WL & 4.129 & 10.449 & $7.696 \pm 1.903$ & 6.154 & 8.658 & $7.214 \pm 0.609$ & 1.379 & 0.246 & 3.2 & \\
\hline NS & 0.014 & 0.027 & $0.021 \pm 0.004$ & 0.023 & 0.031 & $0.026 \pm 0.002$ & 30.385 & $<0.0001$ & & 9.6 \\
\hline WWP & 0.284 & 0.492 & $0.399 \pm 0.054$ & 0.403 & 0.578 & $0.462 \pm 0.041$ & 21.926 & $<0.0001$ & & 7.3 \\
\hline DLL & 0.080 & 0.159 & $0.127 \pm 0.023$ & 0.122 & 0.189 & $0.150 \pm 0.017$ & 16.696 & 0.000 & & 8.5 \\
\hline DCPL & 0.015 & 0.040 & $0.025 \pm 0.006$ & 0.016 & 0.035 & $0.026 \pm 0.005$ & 0.322 & 0.573 & & 1.8 \\
\hline DCSL & 0.184 & 0.309 & $0.253 \pm 0.031$ & 0.167 & 0.307 & $0.223 \pm 0.031$ & 11.463 & 0.001 & 6.2 & \\
\hline PNCLL & 0.037 & 0.110 & $0.080 \pm 0.015$ & 0.040 & 0.086 & $0.066 \pm 0.011$ & 12.614 & 0.001 & 9.3 & \\
\hline VCL & 0.059 & 0.143 & $0.099 \pm 0.020$ & 0.073 & 0.112 & $0.085 \pm 0.009$ & 9.067 & 0.004 & 7.2 & \\
\hline DLS & 0.065 & 0.162 & $0.123 \pm 0.022$ & 0.132 & 0.197 & $0.161 \pm 0.018$ & 42.182 & $<0.0001$ & & 13.1 \\
\hline DCPS & 0.014 & 0.036 & $0.023 \pm 0.007$ & 0.016 & 0.042 & $0.025 \pm 0.006$ & 1.095 & 0.301 & & 3.9 \\
\hline DCSS & 0.154 & 0.279 & $0.230 \pm 0.031$ & 0.142 & 0.268 & $0.194 \pm 0.028$ & 18.012 & $<0.0001$ & 8.4 & \\
\hline PNCLS & 0.032 & 0.112 & $0.078 \pm 0.017$ & 0.040 & 0.084 & $0.065 \pm 0.012$ & 11.254 & 0.002 & 9.6 & \\
\hline VCS & 0.067 & 0.139 & $0.100 \pm 0.018$ & 0.067 & 0.108 & $0.085 \pm 0.010$ & 11.944 & 0.001 & 7.7 & \\
\hline HW & 0.205 & 0.281 & $0.235 \pm 0.020$ & 0.185 & 0.265 & $0.218 \pm 0.021$ & & & & \\
\hline HL & 0.090 & 0.157 & $0.128 \pm 0.017$ & 0.098 & 0.153 & $0.121 \pm 0.013$ & 2.341 & 0.133 & 2.6 & \\
\hline LA & 133.55 & 360.21 & $235.76 \pm 45.30$ & 105.40 & 220.68 & $159.05 \pm 31.87$ & 47.964 & $<0.0001$ & 19.4 & \\
\hline PP & 0.028 & 0.052 & $0.039 \pm 0.006$ & 0.024 & 0.037 & $0.031 \pm 0.003$ & 39.157 & $<0.0001$ & 12.3 & \\
\hline PS & 130.57 & 223.77 & $168.91 \pm 27.77$ & 61.88 & 165.44 & $126.68 \pm 23.65$ & 33.523 & $<0.0001$ & 14.3 & \\
\hline DAE & 0.155 & 0.231 & $0.193 \pm 0.019$ & 0.147 & 0.212 & $0.175 \pm 0.017$ & & 11.286 & 0.002 & 4.7 \\
\hline DPE & 0.138 & 0.199 & $0.173 \pm 0.016$ & 0.133 & 0.193 & $0.165 \pm 0.015$ & 3.562 & 0.065 & 2.5 & \\
\hline DAPE & 0.022 & 0.042 & $0.032 \pm 0.004$ & 0.019 & 0.033 & $0.025 \pm 0.004$ & 32.043 & $<0.0001$ & 11.0 & \\
\hline
\end{tabular}

\section{Population size-structure}

A total of 275 worms were collected during this study, 246 infesting S. plana (241 during the seasonal monitoring, five in January 2013), 26 in M.pellucida (plus three outside the host, but in the same container) (Table 9). Sizes ranged from 1.8 to $3.6 \mathrm{~mm}$. Small-sized worms seem to be better represented during late autumn, but also in winter, while large worms were more or less constantly present throughout the study period, except during late winter and early spring (Fig. 4).

Ripe females occurred during the whole period except in April 2012, and were always among the largest size-classes (2.2 to $3.6 \mathrm{~mm}$ ) (Fig. 4). The highest percentages occurred in mid spring and summer, being August 2011 the single month during which the proportion ripe females $v s$. non-sexed adults sexes was 1:1 (Fig. 5; Table 9). The lowest percentages occurred in autumn and winter (Fig. 5; Table 9).

A total of 6,917 specimens of S. plana and 39 of $M$. pellucida were collected (Table 9). Length in S. plana ranged from 20 to $40 \mathrm{~mm}$, with the exception of one infested host measuring $40.7 \mathrm{~mm}$. However, bivalves with intermediate lengths (i.e., 26-36 mm) occurred during the whole year, being always the most abundant and also the most infested ones (Fig. 6). The most balanced size class frequency distribution occurred in September 2011. In M. pellucida, the size-class range was restricted to $20-30 \mathrm{~mm}$ length, and the most infested ones were slightly smaller (20-28 mm) than in S. plana (Fig. 6).

Overall, there was a non-significant size correlation between $O$. okupa sp. nov. and the host S. plana (Pearson coefficient $=0.123, p=0.067$ ). The monthly trends were also non-significant (Pearson coefficient $=-0.375$ to $0.351, p=0.103$ to 0.818$)$, except for a positive correlation in April 2012 (Pearson coefficient $=0.870, \mathrm{p}=$ 0.011). Conversely, O. okupa sp. nov. / M. pellucida symbiont-host pairs (26) collected in January 2013 showed a significant, positive size correlation (Pearson coefficient $=0.400, \mathrm{p}=0.021$ ).

\section{Infestation characteristics}

The studied population of O. okupa sp. nov. showed a seasonal variability in prevalence (Fig. 5; Table 9). The highest percentages occurred during late autumn-mid 


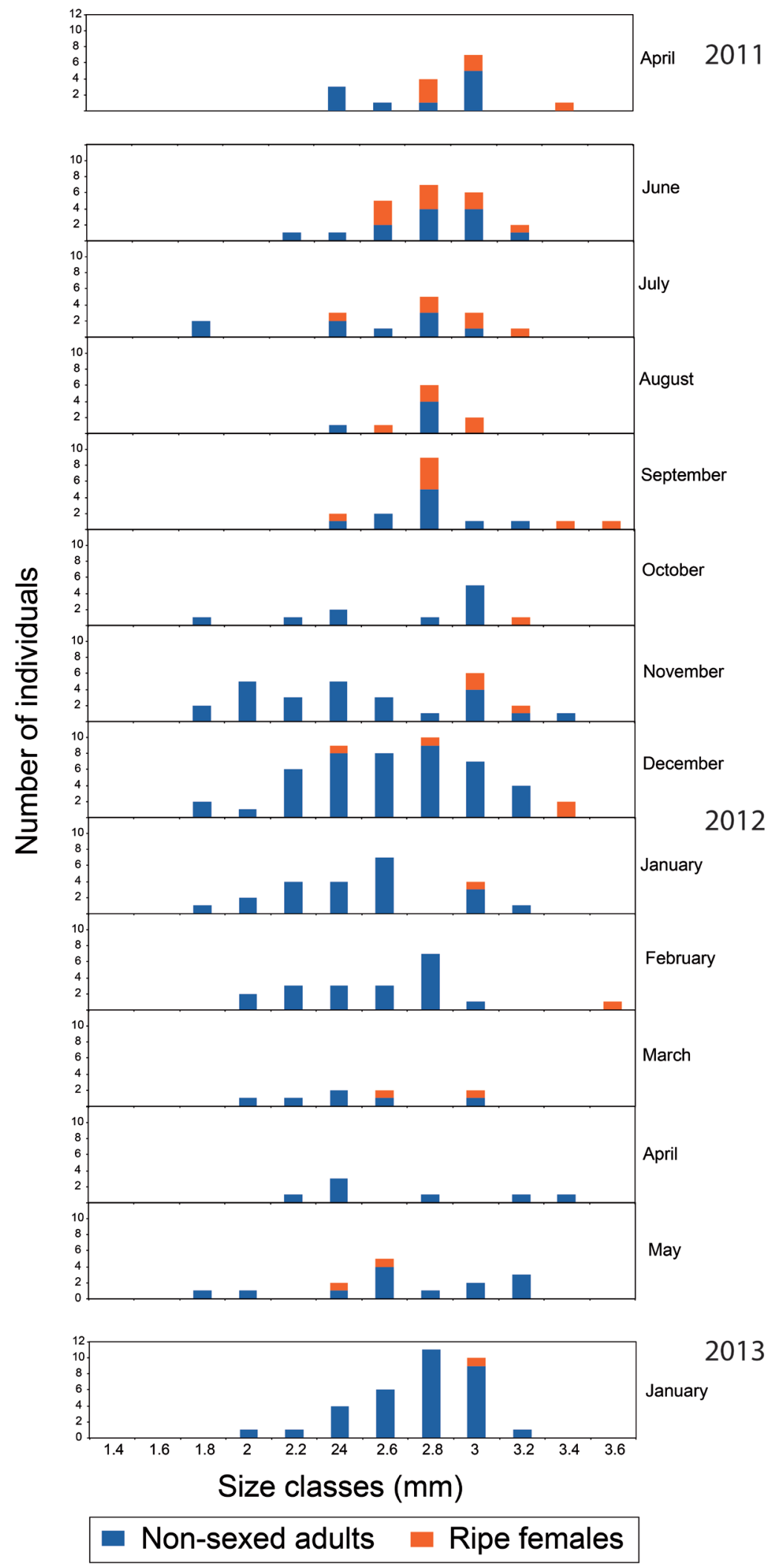

Fig. 4. Oxydromus okupa sp. nov. Sizefrequencies of the specimens hosted by Scrobicularia plana from April 2011 to May 2012, and by Macomopsis pellucida in January 2013. 2011: April, $\mathrm{n}=16$; June, $\mathrm{n}=22$; July, $\mathrm{n}=15$; August, $\mathrm{n}=10$; September, $\mathrm{n}=17$; October, $\mathrm{n}=11$; November, $n=28$; December, $n=49.2012$ : January, $\mathrm{n}=23$; February, $\mathrm{n}=20$; March, $\mathrm{n}=8 ;$ April, $\mathrm{n}=7$; May, $\mathrm{n}=15 ; 2013$ : January, $\mathrm{n}=26$. 
Table 7. List of the ten most contributing measurement proportions to the intra-population similarities and inter-population dissimilarity based on the SIMPER analyses. Measurement abbreviations as in Fig. 1. Av.Value: Average value; Av.Sq.Dist: average square distance; Sq.Dist/SD: square distance divided by standard deviation; Contrib\%: percentage of contribution; Cum.\%: cumulative percentage of contribution.

\begin{tabular}{|c|c|c|c|c|c|c|}
\hline Iberian & & Av.Value & Av.Sq.Dist & Sq.Dist/SD & Contrib\% & Cum.\% \\
\hline DAPE/HL & & 0.531 & 0.729 & 0.50 & 3.41 & 3.41 \\
\hline DCSS/DL & & 0.663 & 0.738 & 0.49 & 3.45 & 6.86 \\
\hline $\mathrm{LA} / \mathrm{HL}$ & & 0.599 & 0.84 & 0.47 & 3.93 & 10.79 \\
\hline DAE/DPE & & 0.481 & 0.863 & 0.47 & 4.04 & 14.82 \\
\hline DPE/HW & & -0.203 & 0.906 & 0.48 & 4.24 & 19.06 \\
\hline DCSS/DL & & 0.515 & 0.913 & 0.49 & 4.27 & 23.33 \\
\hline PS/HL & & 0.518 & 0.936 & 0.51 & 4.38 & 27.70 \\
\hline PP/HL & & 0.495 & 0.97 & 0.50 & 4.54 & 32.24 \\
\hline WWP/WW & & -0.527 & 0.977 & 0.49 & 4.57 & 36.81 \\
\hline NS/WW & & -0.578 & 0.991 & 0.49 & 4.63 & 41.44 \\
\hline Congolese & & Av.Value & Av.Sq.Dist & Sq.Dist/SD & Contrib\% & Cum.\% \\
\hline WL/WW & & -0.176 & 0.175 & 0.47 & 1.58 & 1.58 \\
\hline NS/WW & & 0.657 & 0.209 & 0.44 & 1.89 & 3.47 \\
\hline DCSS/DL & & -0.753 & 0.23 & 0.48 & 2.07 & 5.54 \\
\hline LA/HL & & -0.68 & 0.319 & 0.50 & 2.87 & 8.41 \\
\hline WWP/WW & & 0.598 & 0.369 & 0.51 & 3.33 & 11.74 \\
\hline $\mathrm{PS} / \mathrm{HL}$ & & -0.589 & 0.439 & 0.37 & 3.96 & 15.69 \\
\hline PP/HL & & -0.563 & 0.458 & 0.46 & 4.13 & 19.82 \\
\hline DCSS/DL & & -0.585 & 0.472 & 0.48 & 4.26 & 24.08 \\
\hline VCS/PNCS & & $-4.07 E-2$ & 0.496 & 0.51 & 4.47 & 28.56 \\
\hline DCSS/DCPS & & -0.477 & 0.545 & 0.46 & 4.92 & 33.47 \\
\hline Variable & $\begin{array}{r}\text { Iberian } \\
\text { Av.Value }\end{array}$ & $\begin{array}{c}\text { Congolese } \\
\text { Av.Value }\end{array}$ & Av.Sq.Dist & Sq.Dist/SD & Contrib\% & Cum.\% \\
\hline DCSS/DL & 0.663 & -0.753 & 2.93 & 0.96 & 6.38 & 6.38 \\
\hline LA/HL & 0.599 & -0.68 & 2.75 & 0.98 & 5.97 & 12.35 \\
\hline NS/WW & -0.578 & 0.657 & 2.67 & 0.81 & 5.82 & 18.17 \\
\hline DAPE/HL & 0.531 & -0.604 & 2.6 & 0.84 & 5.65 & 23.82 \\
\hline WWP/WW & -0.527 & 0.598 & 2.56 & 0.84 & 5.56 & 29.38 \\
\hline $\mathrm{PS} / \mathrm{HL}$ & 0.518 & -0.589 & 2.54 & 0.74 & 5.53 & 34.91 \\
\hline DCSS/DL & 0.515 & -0.585 & 2.54 & 0.77 & 5.52 & 40.43 \\
\hline $\mathrm{PP} / \mathrm{HL}$ & 0.495 & -0.563 & 2.49 & 0.91 & 5.41 & 45.84 \\
\hline DAE/DPE & 0.481 & -0.546 & 2.47 & 0.87 & 5.38 & 51.22 \\
\hline DCSS/DCPS & 0.42 & -0.477 & 2.33 & 0.81 & 5.07 & 56.28 \\
\hline
\end{tabular}

winter. The highest peak was in December 2011 (i.e. $19.2 \%$ ), in coincidence with the highest number of symbionts (Table 9). Intermediate prevalences occurred in November 2011 (i.e. 7.2\%), January 2012 (i.e. $8.2 \%$ ) and February 2012 (i.e. 6.1\%). The remaining prevalences were always $<5 \%$ and the lowest one occurred in April 2011 (i.e. 1.6\%). The intensity of the infestation was always a single worm per host. In the case of the specimens associated with M.pellucida, the prevalence was $66.7 \%$ (Table 9), reaching $89.3 \%$ in hosts $>20 \mathrm{~mm}$ long (Fig. 6).
There was a non-significant correlation between the percentage of ripe females and prevalence in S. plana along the studied period (Pearson coefficient $=-0.407$, $p=0.168)$. However, the percentage of ripe females was, on average, significantly higher (one-way ANO$\mathrm{VA}, \mathrm{F}=9.253, p=0.011$ ) in the warm than in the cold period, reaching $31.0 \pm 4.8 \%$ and $7.5 \pm 6.1 \%$, respectively, while the prevalence showed exactly the contrary pattern, $3.2 \pm 1.3 \%$ vs. $8.9 \pm 1.7 \%$ (one-way ANOVA, $\mathrm{F}=$ 7.066, $p=0.022)($ Fig. 5) 
Table 8. Comparative table of the morphometric measurement proportions in the Iberian and Congolese populations. Differences expressed as percentages, with bold characters indicating significant differences (according to Benjamini and Hochberg, 1995) that may be higher (normal text) or lower (italics) in the Iberian than in the Congolese population. Measurement abbreviations as in Fig. 1. Min: minimum; Max: maximum; Mean: average \pm standard deviation; F: Fisher's F index; p: significance level.

\begin{tabular}{|c|c|c|c|c|c|c|c|c|c|c|}
\hline \multirow[b]{2}{*}{ SD } & \multicolumn{3}{|c|}{ Iberian Population } & \multicolumn{3}{|c|}{ Congolese Population } & \multicolumn{2}{|c|}{ ANOVA } & \multicolumn{2}{|c|}{ Difference } \\
\hline & Min & Max & Mean & Min & $\operatorname{Max}$ & Mean & $\mathbf{F}$ & $p$ & & $\%$ \\
\hline WL/WW & 4.129 & 10.449 & $7.696 \pm 1.903$ & 6.154 & 8.658 & $7.214 \pm 0.609$ & 1.379 & 0.246 & 3.2 & \\
\hline NS/WW & 0.014 & 0.027 & $0.021 \pm 0.004$ & 0.023 & 0.031 & $0.026 \pm 0.002$ & 30.385 & $<0.0001$ & & 9.6 \\
\hline WWP/WW & 0.284 & 0.492 & $0.399 \pm 0.054$ & 0.403 & 0.578 & $0.462 \pm 0.041$ & 21.926 & $<0.0001$ & & 7.3 \\
\hline DCPL/DLL & 0.125 & 0.314 & $0.201 \pm 0.053$ & 0.100 & 0.253 & $0.175 \pm 0.041$ & 3.809 & 0.057 & 6.9 & \\
\hline DCSL/DLL & 1.309 & 3.038 & $2.061 \pm 0.449$ & 0.961 & 2.211 & $1.513 \pm 0.316$ & 24.871 & $<0.0001$ & 15.3 & \\
\hline DCSL/DCPL & 5.501 & 17.797 & $10.658 \pm 2.530$ & 6.814 & 13.446 & $8.886 \pm 1.915$ & 7.806 & 0.007 & 9.1 & \\
\hline VCL/PNCL & 0.709 & 2.477 & $1.281 \pm 0.361$ & 0.949 & 2.049 & $1.326 \pm 0.276$ & 0.246 & 0.622 & & 1.7 \\
\hline DCPS/DLS & 0.124 & 0.324 & $0.193 \pm 0.057$ & 0.092 & 0.251 & $0.160 \pm 0.041$ & 5.464 & 0.024 & 9.3 & \\
\hline DCSS/DLS & 1.220 & 2.750 & $1.920 \pm 0.406$ & 0.826 & 1.716 & $1.226 \pm 0.229$ & 55.281 & $<0.0001$ & 22.1 & \\
\hline DCSS/DCPS & 5.920 & 16.985 & $10.520 \pm 2.915$ & 4.934 & 12.884 & $8.013 \pm 2.011$ & & 12.531 & 0.001 & 13.5 \\
\hline VCS/PNCS & 0.897 & 3.332 & $1.350 \pm 0.504$ & 0.888 & 2.673 & $1.377 \pm 0.387$ & 0.046 & 0.831 & & 1.0 \\
\hline $\mathrm{HL} / \mathrm{HW}$ & 0.420 & 0.642 & $0.545 \pm 0.059$ & 0.430 & 0.680 & $0.559 \pm 0.057$ & 0.727 & 0.398 & & 1.3 \\
\hline $\mathrm{LA} / \mathrm{HL}$ & 0.362 & 0.967 & $0.721 \pm 0.145$ & 0.400 & 0.690 & $0.518 \pm 0.092$ & 34.956 & $<0.0001$ & 16.4 & \\
\hline $\mathrm{PP} / \mathrm{HL}$ & 0.215 & 0.395 & $0.309 \pm 0.049$ & 0.211 & 0.341 & $0.254 \pm 0.032$ & 21.893 & $<0.0001$ & 9.8 & \\
\hline $\mathrm{PS} / \mathrm{HL}$ & 0.356 & 0.698 & $0.517 \pm 0.095$ & 0.204 & 0.533 & $0.413 \pm 0.066$ & 20.384 & $<0.0001$ & 11.2 & \\
\hline $\mathrm{PS} / \mathrm{PP}$ & 1.171 & 2.641 & $1.707 \pm 0.385$ & 0.751 & 2.206 & $1.651 \pm 0.319$ & 0.311 & 0.580 & 1.7 & \\
\hline DAE/HW & 0.741 & 0.924 & $0.821 \pm 0.042$ & 0.725 & 0.871 & $0.805 \pm 0.035$ & 2.179 & 0.146 & 1.0 & \\
\hline DPE/HW & 0.660 & 0.832 & $0.738 \pm 0.042$ & 0.677 & 0.852 & $0.758 \pm 0.043$ & 2.744 & 0.104 & & 1.3 \\
\hline DAPE/HL & 0.195 & 0.303 & $0.250 \pm 0.031$ & 0.155 & 0.269 & $0.211 \pm 0.028$ & 22.185 & $<0.0001$ & 8.6 & \\
\hline DAE/DPE & 1.021 & 1.198 & $1.113 \pm 0.046$ & 1.004 & 1.148 & $1.063 \pm 0.042$ & 16.107 & 0.000 & 2.3 & \\
\hline
\end{tabular}

\begin{tabular}{|c|c|c|c|c|c|c|}
\hline Year & Month & Hosts & & $\begin{array}{l}\% \text { Ripe } \\
\text { Females }\end{array}$ & Prevalence & Host species \\
\hline & & Total & Infested & & & \\
\hline \multirow[t]{8}{*}{2011} & April & 1000 & 16 & 37.5 & 1.6 & S.plana \\
\hline & June & 468 & 22 & 40.9 & 4.7 & \\
\hline & July & 469 & 15 & 40.0 & 3.2 & \\
\hline & August & 370 & 10 & 50.0 & 2.7 & \\
\hline & September & 370 & 17 & 41.2 & 4.6 & \\
\hline & October & 306 & 11 & 9.1 & 3.6 & \\
\hline & November & 389 & 28 & 10.7 & 7.2 & \\
\hline & December & 255 & 49 & 8.2 & 19.2 & \\
\hline \multirow[t]{5}{*}{2012} & January & 280 & 23 & 4.3 & 8.2 & \\
\hline & February & 328 & 20 & 5.0 & 6.1 & \\
\hline & March & 320 & 8 & 25.0 & 2.5 & \\
\hline & April & 219 & 7 & 0.0 & 3.2 & \\
\hline & May & 469 & 15 & 13.3 & 3.2 & \\
\hline 2013 & January & 39 & 26 & 2.9 & 66.7 & P. cumana \\
\hline
\end{tabular}

Table 9. Oxydromus okupa sp. nov. Synthesis of the monthly captures, total and infested number of hosts, percentage of ripe females, and prevalence during the study period.

\section{Discussion}

\section{Morphometry and taxonomy}

Molecular analyses currently tend to displace morphometry in studies trying to discriminate within closely related morphotypes for taxonomic purposes (Blaxter, 2004; Hebert and Gregory, 2005; Godfray, 2007). However, most taxonomists agree that combining the different approaches, applying the socalled Integrative Taxonomy, is the most effective strategy to build a stable and robust taxonomy (Will 


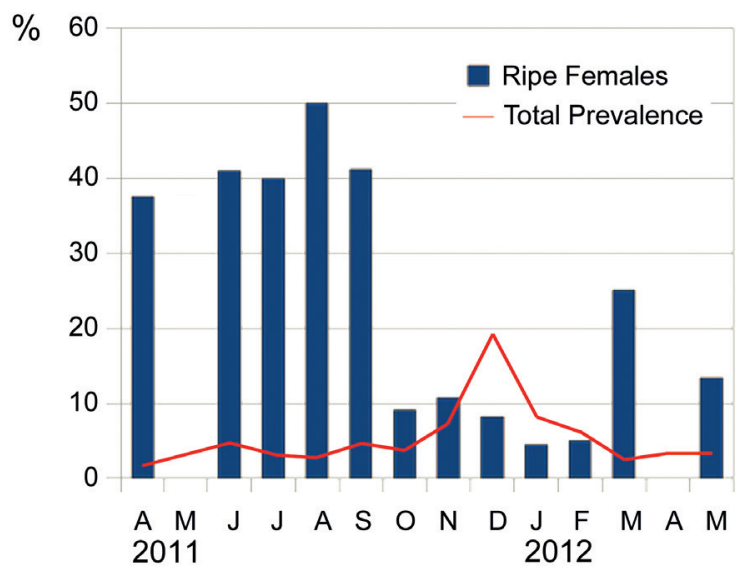

Fig. 5. Oxydromus okupa sp. nov. Monthly prevalence of ripe females vs. total prevalence in the infested Scrobicularia plana.

et al., 2005; Padial et al., 2010). Hence, the importance of morphology must not be forgotten in the genomics era (Giribert, 2015). Moreover, it is not always possible to obtain adequate material for genetic studies because the used preservation methods are destructive, while there is no fresh material available. In such cases morphometry may be the only approach allowing to identify distinguishing characters within species complexes.

Among polychaetes, many taxonomically robust morphological characters may be defined by measurements and/or proportions, some of them being size-dependent (Ben-Eliahu, 1987; Fauchald, 1991; Sigvaldadóttir and Mackie, 1993). This approach has been used independently of molecular analyses to successfully resolve the taxonomy of several sibling species complexes, often leading to the description of new species (Orrhage and Sundberg, 1990; Fauchald, 1991; Blake, 2000; Koh and Bhaud, 2003; Koh et al., 2003; Martin et al., 2003, 2006, 2009; Ford and Hutchings, 2005; Garraffoni and de Garcia Camargo, 2006; Glasby and Glasby, 2006; Lattig et al., 2007; Hernández-Alcántara and Solís-Weiss, 2014; Coutinho et al., 2015). However, Ford and Hutchings (2005) were the first to consider the use of the statistical dissimilarities derived from the SIMPER routine of the PRIMER software (Clarke and Warwick, 2001; Clarke and Gorley, 2006), based on a matrix of morphometric measurements, as a robust support to distinguish between morphologically close species. Accordingly, they described three new species whose average dissimilarities ranged between 11-19\%, later finding morphological evidences supporting the erection of the new species. Our morphometric approach, in turn, clearly discriminates the two populations of "O. humesi" which, despite their close morphologies, showed average dissimilarities ranging from 30 to $36 \%$ in the SIMPER, thus almost three times higher than the Australian species of Owenia. A detailed comparison of character variability, particularly those that were responsible for the intra-population similarity and the inter-population dissimilarity, led to a reliable way to solve this question. There were significant differences in size range between the Iberian and the Congolese populations (more restricted in the later, leading us to find less size-correlated parameters in Congolese worms). Our approach to compare the two populations led to evident and consistent differences in the appendage measurements and relative proportions (Tables 6,8 ) that are considered as robust enough to formally describe the Iberian specimens as the new species $O$. okupa sp. nov. In addition, we further validate these differences by means of discriminant analyses, whose respective discriminant functions were able to identify the members of the two species with a reliability of 96 to $100 \%$ in all tests.

\section{Infestation characteristics}

Host/symbiont size relationships. Positive host/symbiont size relationships may either indicate 1) active size segregation behaviour, as reported both for the symbiotic coral dwelling crab Trapezia bidentata (Forskål, 1775) (Adams et al., 1985) and the fish Gobiodon histrio (Valenciennes, 1837) (Hobbs and Munday, 2004), which seem to be able to migrate from colony to colony to choose one of an appropriate size, or 2) parallel growth of hosts and symbionts, as reported both for the nemertean Malacobdella grossa (Müller, 1776), hosted by Arctica islandica (Linnaeus, 1767) (Sundet and Jobling, 1985) and the pontoniin shrimp Anchistus custos (Forskål, 1775), hosted by the bivalve Pinna bicolor Gmelin, 1791 (Britayev and Fahrutdinov, 1994). In turn, the absence of host/symbiont size correlation could be caused by symbionts that either colonize the hosts during a single phase of their life-history (e.g. juveniles, adults), that are highly mobile (thus, colonizing the available host independently of their size), or growth faster than the host, even if the infestation starts with juveniles colonizing small-sized hosts (Britayev et al., 2007).

Among symbiotic polychaetes, positive host/symbiont size-relationships are not common (Martin and Britayev, 1998) and, when occurring, they may be modified by differential behaviour linked to, for instance, 

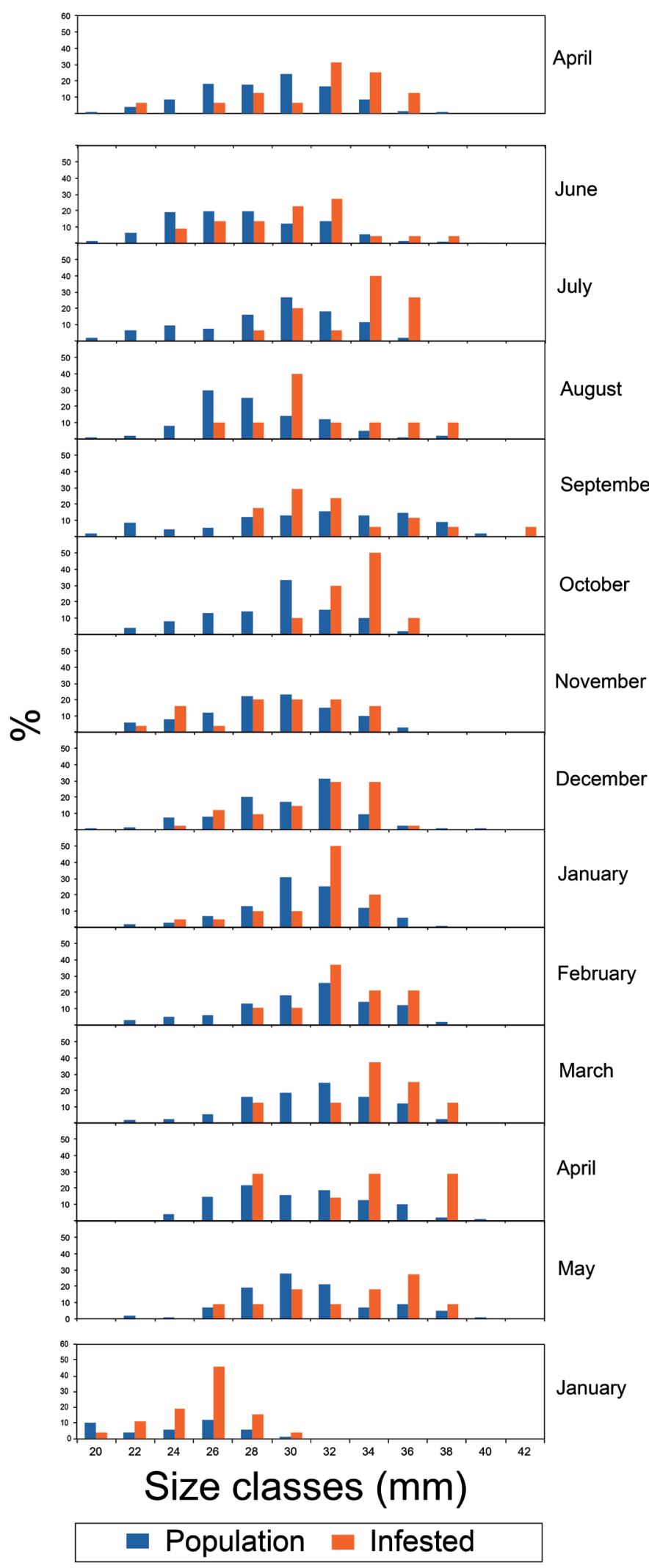

\section{3} January
Fig. 6. Size-frequencies of the total vs. infested Scrobicularia plana from April 2011 to May 2012 and Macomopsis pellucida in January $2013(\mathrm{n}=39)$. Monthly total number of individuals of S. plana: 2011: April, $\mathrm{n}=300$; June, $\mathrm{n}=200$; July, $\mathrm{n}=94$; August, $\mathrm{n}=100$; September, $\mathrm{n}=$ 108; October, $\mathrm{n}=99$; November, $\mathrm{n}=99$; December, $\mathrm{n}=124$. 2012: January, $\mathrm{n}=$ 100; February, $\mathrm{n}=98$; March, $\mathrm{n}=150$; April, $\mathrm{n}=102 ;$ May, $\mathrm{n}=100$. 
reproductive activities. This seems to be the case of Branchipolynoe seepensis Pettibone, 1986, an obligate symbiont of deep-sea hydrothermal vent mytilids of the genus Bathymodiolus, whose females have a longer life span than males and remain inside the same host along their whole life, while males leave their original hosts for mating and then colonize the available hosts independently of their size. Consequently, positive host/symbiont size correlations occur only for females and for non-mature males (Britayev et al., 2007). In most known cases, however, the relationship between size structure of symbiotic polychaetes and their hosts is unclear (Martin et al., 1991, 1992; Emson et al., 1993; Rozbaczylo and Cañete, 1993; Britayev and Zamyshliak, 1996) so that the life histories of the former have been considered to be independent of that of the latter, with the hosts tending to live longer and commonly hosting successive symbionts (Martin and Britayev, 1998).

The absence of host/symbiont size-relationships previously reported for the intertidal population of $O . o k u$ pa sp. nov. (Martin et al., 2012) was here confirmed by the absence of significant correlations found along the whole study period. The only exception was April 2012, which we consider as a spurious relationship due to the low number of collected worms $(\mathrm{n}<10)$ (Fig. 4; Table 9). However, other months with a similar number of individuals (e.g. $\mathrm{n}=8$ - 11 in March, October, and August) (Fig. 4; Table 9) showed non-significant relationships. These results support Martin et al. (2012) in that the worms do not grow together with their hosts in their intertidal environment. In turn, O. okupa sp. nov. was reported to infest specimens of S. plana $>20 \mathrm{~mm}$ in shell length and to be more frequent in intermediate-sized shells, 26-36 mm long (Martin et al., 2012), which has also been confirmed along the whole period of study. Limiting host sizes have been reported for the starfish Asterias rathbuni (Verrill, 1909) in Vostok Bay (Sea of Japan), whose specimens with disc radii lower than 35 $\mathrm{mm}$ were not inhabited by Arctonoe vittata (Grube, 1855), and those with radii up to $90 \mathrm{~mm}$ harboured one single symbiont, whereas the largest starfishes could host up to four polychaetes (Britayev et al., 1989). Another example occurs in Chile, where the scale-worm Harmothoe commensalis Rozbaczylo and Cañete, 1993 did not occur in specimens of the clam Gari solida (Gray, 1828) < $60 \mathrm{~mm}$ in shell length (Rozbaczylo and Cañete, 1993). The size-limit for $S$. plana as a host of $O$. okupa sp. nov., also implied that there were no small juveniles infesting small-sized hosts, which allows us to discard the fast-growing hypothesis for this new species.
On the other hand, the infested specimens of M.pellucida collected in a subtidal environment during January 2013 included a considerable amount of small-sized hosts (Fig. 6). Moreover, there was a significant positive size correlation between hosts and symbionts. This relationship may be caused either by the symbiont selecting the host to be infested according to the appropriateness of its size, or by host/symbiont parallel growth, which cannot be assessed in light of our present data. Despite the low number of collected bivalves, the existing size relationship and the very high infestation rates (Table 9), suggest together that M. pellucida and the subtidal environment could be the preferred host and habitat for O. okupa sp. nov., with the symbiont selecting the most suitable hosts when conditions are optimal.

Prevalence of the infestation. The prevalence of commensal polychaetes is highly variable and has been considered as a species-specific characteristic. However, a commensal species may also show different prevalences, which may vary according to bathymetric, spatial and temporal (i.e. intra- and inter-annual) patterns (Martin and Britayev, 1998). Studies including temporal trends are, however, scarce. With the exception of the impressive fidelity of the year-to-year counts of a regular seasonal trend reported for the infestation prevalence of Ophiocoma echinata (Lamarck, 1816) by Branchiosyllis exilis (Gravier, 1900) in Panamá (Hendler and Meyer, 1982), the only known data on year-to-year variability for a symbiotic polychaete are probably those on Arctonoe vittata (Grube, 1855). In Vostok Bay, this worm infests the starfish Asterias amurensis Lütken, 1871 with a progressive increase in prevalence from 0\% in 1975-76 to $8.4 \%$ in 1978 and to $79.1 \%$ in 1980 (Britayev, 1991). Based on our study period, O. okupa sp. nov. seems to show a seasonal trend in prevalence, with the highest percentages occurring during the coldest seasons, i.e. from late autumn to late winter (Fig. 5; Table 9). The present dataset only covers a single year and therefore inter-annual regularities cannot be inferred.

Theoretically, we may expect an influence of the host's population structure on that of the symbiont (Martin \& Britayev, 1998). A positive relationship between host density and infestation characteristics was reported for A. vittata and its host starfish A. rathbuni in Vostok Bay (Britayev et al., 1989). The highest prevalence, mean intensity and abundance depended upon host's density, which could be caused by the accumulation of a chemically-mediated host-cue more effectively attracting the settling symbionts. High host densities may also reduce the influence of external factors. For 
instance, commensals associated with less abundant host populations may experience a more relevant decrease in fitness than those harboured by dense host populations (Martin and Britayev, 1998).

Among the few relationships with known data, high infestation indexes tend to be positively correlated with the availability of large and numerous hosts to be occupied by the symbionts (Martin and Britayev, 1998). In the present case, the overall low prevalence would lead to the expectation of a low number of S. plana $>20$ $\mathrm{mm}$ long in the study area. Conversely, S. plana was very abundant independently of size (Subida et al., 2011; Drake et al., 2014) and so numerous adequate hosts were available through the whole study period (Fig. 6; Table 9). Therefore, the prevalence seems not to be connected with the host availability. In turn, this low prevalence could be related to the extreme daily changes in temperature and/or the alternating long desiccation/immersion periods that characterize the intertidal environment, as well as with biota disturbance due to bait digging of this zone at Río San Pedro (Carvalho et al., 2013). The high prevalence in the subtidal population of M.pellucida (i.e. higher than $85 \%$ in specimens $>20 \mathrm{~mm}$ long), seems to confirm this hypothesis, with the permanent immersion in the subtidal environment favouring the presence of the symbiont.

The fact that no specimens of S. plana $<18 \mathrm{~mm}$ in shell length were found during the annual cycle, is in agreement with all previous data obtained in punctual samplings (Martin et al. 2012, 2015). The present approach did not clarify this peculiarity of the studied bivalve population. However, the high density of specimens restricted to the narrow intertidal area at Río San Pedro led to postulate the existence of a negative interaction between the established population and the settling larvae, which could be actively ingested by their conspecific adults during their normal filter/suspension feeding activities (i.e. passive cannibalism) (CargninFerreira, 2005; Santos et al. 2011).

The association of a symbiont with various hosts in the same locality could affect the prevalence, which strongly depends on its level of affinity for the different hosts. Although the symbiotic population of $O$. okupa sp. nov. at Río San Pedro only infested S. plana, this factor could not be eventually discarded due to the presence of the nearby subtidal population of M. pellucida at the opening of Río San Pedro.

Infestation intensity. The infestation intensity of symbiont polychaetes has been more widely reported than the prevalence. It may range from one to hundreds of sym- bionts per host, but is clearly dominated by the association of a single symbiont per host either due to the usually low symbiont densities or to the influence of an intraspecific aggressive behaviour (Martin and Britayev, 1998). Like the prevalence, intensity may also oscillate within the same population due to seasonal changes in relative abundances, linked or not to reproduction and recruitment events. A common situation for symbionts with 1:1 regular distributions like $O$. okupa sp. nov., is that adults may occasionally share the host with one to several juveniles, as previously reported for polychaete species of the genera Acholoe, Adyte or Branchiosyllis, among others (Martin and Britayev, 1998).

In the case of O. okupa sp. nov., Martin et al. (2012, 2015) reported single findings of one male and one female and one male, one female and one small worm, likely a juvenile sharing the same host, while the constant regular distribution of one single symbiont per host was attributed to intraspecific aggressive behaviour. There are several cases of symbiotic polychaetes with male and female couples living together associated with the same host, such as the Mediterranean fish parasite Ichthyotomus sanguinarius Eisig, 1906 (Eisig, 1906; Culurgioni et al., 2006) or the deep-sea hexactinellid sponge symbiont Robertianella synophthalma McIntosh, 1885, reported as Harmothoe hyalonemae in Martin et al. (1992). However, in both cases, most hosts harboured couples, while in O. okupa sp. nov. couples seemed to be the exception.

Life-cycle

Little is known about the life cycle of most commensal polychaetes and, when known usually does not differ much from that of their free-living relatives. Thus, it is expected to find planktonic larvae (responsible of dispersal and colonization) and benthic adults (with a somewhat reduced mobility) with the single main difference that the symbiotic mode of life replaces the freeliving one during the benthic phase (Martin and Britayev, 1998). Larval settlement may occur on the bottom, being then followed by a juvenile migration towards the respective hosts (Davenport and Boolootian, 1966). However, it seems more likely that chemically mediated cues (either generated by the host or by the own symbiotic adults) driving larval settlement could be the most widespread behaviour among symbiotic polychaetes (parasites included) (Martin and Britayev, 1998).

As it occurs for the free-living species, this basic life-cycle scheme may vary in many ways as a result of the adaptation to a symbiotic mode of life. For instance, 
it can be simplified by reducing (or even eliminating) the free-living pelagic stage or become more complex by having one or more intermediate hosts, which are occupied when the preferred ones are not available or because they have more room to host several juveniles during growing period (Martin and Britayev, 1998). Herewith, intraspecific competition and aggression may play a major role in the associated relocation processes. In the case of $O$. okupa sp. nov., the only information known on the juveniles is that they have not been found inside $S$. plana, neither free-living, which has been confirmed during the studied period.

The highest number of small worms found inside $S$. plana occurred in late autumn, which could be considered as an indication of new symbiont's recruitment into the host bivalves (after the population being more actively reproducing during summer). In turn, large adults tended to disappear around mid-winter. This may suggest that the life span of O. okupa sp. nov. may be of one year, with the adults dying after reproducing. However, sampling during successive years would be required to confirm this hypothesis, as well as to assess the regularity of the recruitment events.

The life cycle of O. okupa sp. nov. may be limited by the tidal regime characteristic of its intertidal habitat, while the highly abundant population living in M. pellucida seems to indicate that recruitment may occur mainly in the more favourable subtidal conditions. Thus, we propose a possible scenario in which the symbionts mainly inhabit certain areas of the Bay not submitted to periodical desiccation by tides, living in association with M. pellucida (but we cannot discard other possible unknown hosts), then reaching intertidal areas such as those at Río San Pedro either as larvae through tidal currents or by adult migration. Therefore, the intertidal area here studied could be at the limit of the ecological distribution of this bivalve endosymbiont in the Cádiz Bay region.

The absence of juveniles inside the studied hosts suggests that this phase may be free-living and that the colonization of S. plana occurs during the benthic phase of the life cycle of $O$. okupa sp. nov., whose adults are able to move up along Río San Pedro with tides. However, neither juveniles, nor adults have been found in the sediments surrounding the studied areas (P. Drake, per. observ.), likely because they may be quite rare.

The possible life cycle of $O$. okupa sp. nov. may thus consist of 1) a planktonic larval phase settling on soft bottoms, 2) free-living juveniles, and 3) adults able to select (whenever possible) and enter the hosts at a given size (i.e., $>1.6 \mathrm{~mm}$ wide according the present results). If so, phase 3 may involve thigmotaxis and the highly specific host entering behaviour described by Martin et al. (2015). In fact, a comparable life cycle was described for the polychaete Neanthes fucata (Savigny in Lamarck, 1818) in hermit crabs, by Gilpin-Brown (1969) off Plymouth. The planktotrophic larvae of this nereidid settle directly on soft bottoms. The juveniles live in tubes for several months feeding on detritus and small benthic animals exactly as many of their freeliving relatives. Then, 4-month old worms start to develop the ability to recognize the presence of potential hosts by the substratum vibrations produced by the hermit crab legs bouncing on the sediment surface, which triggers a characteristic host-entering behaviour that allows the worms to crawl on the hermit crab shell following the shell spirals by thigmotaxis (Gilpin-Brown, 1969). This complex life cycle uses different mechanisms that characterize the free-living nereidids (such as thigmotaxis or mucus production) as specific adaptations to the commensal mode of life, while the worm itself has no relevant morphological adaptations. Therefore, in addition to the similarity of the hypothesized life cycle of $O$. okupa sp. nov., both species also share the lack of evident morphological adaptations (maybe except for the reduction of the central antennae in the hesionid, whose significance in terms of adaptation to the symbiotic mode of life remains unclear) and an equivalent, highly specific host entering behaviour.

The mechanism of host-recognition behaviour in $O$. okupa sp. nov. is currently unknown, and the presence of a host-factor has not been demonstrated (Martin et al., 2012, 2015). However, it is well known that the bivalves hosting $O$. okupa sp. nov. may alternate between direct water filtration and deposit feeding by tapping on the sediment surface with their inhalant siphons. Thus, we may hypothesize that the symbiont, like $N$. fucata, may recognize the presence of a potential host by the movements of the inhalant siphon. Despite aforementioned similarities between the known hosts of $\mathrm{O} . \mathrm{oku}$ $p a$ sp. nov., there is no direct evidence of the symbiont entering into M. pellucida (or any other potential host) in a similar way as into S. plana.

Relationships between life-cycle and infestation characteristics

The infestation in O.okupa sp. nov., seemed to be connected with the reproduction. The months with lower prevalence (i.e., mid spring and summer) showed a markedly higher percentage of ripe females $(>30 \%)$ (Fig. 4, 5; Table 9), reaching a 50\% in August 2011, while the coldest month (i.e. October 2011 to February 
2012) showed a high prevalence coupled with low percentages of ripe females (Fig. 4, 5; Table 9). The marked seasonal pattern found in the population of O.pugettensis (Johnson, 1901) infesting the starfish Patiria miniata (Brandt, 1835) at Dana Point (California) seemed also to be connected with the commensal reproductive dynamics (Lande and Reish, 1968). This species reached the highest $(\geq 80 \%)$ and lowest $(\leq 30 \%)$ prevalence in November-December and prior to the decrease of water temperature in summer, respectively. Its abundance was maximum in winter (2-3 worms per host) and minimum at mid-summer ( $<0.5$ worms per host).

Despite sampling on different years is certainly required to infer regularities in the relationships between prevalence and life cycle in $O$. okupa sp. nov., these observations suggests that ripe females may have a reduced mobility (i.e., they tend to remain inside the host during their whole life), whereas males could be more mobile and thus leave their host, likely to increase fertilization success. Taking into account that $O$. okupa sp. nov. has a 1:1 regular distribution, the higher mobility attributed to males may contribute to an increase fertilization success by increasing the possibility of male/ female partnership. Two possible mechanisms may explain this: 1) males may directly enter a host occupied by a ripe female, or 2) males may approach a host when females are releasing their sexual products. In both cases, we suggest that chemical cues may be involved. A similar behaviour was previously reported for $B$. seepensis, and, as mentioned above, also contributed to explain the lack of host-bivalve size relationships for adult males (Britayev et al., 2007). A similar situation was also reported for Haplosyllides floridana Augener, 1922, whose male stolons were never found inside the host sponge Neofibularia nolitangere (Duchassaing \& Michelotti, 1864) and, conversely, were found freeswimming in the water column (Martin et al., 2009). Accordingly, the highest prevalence in the studied population of $O$. okupa sp. nov. occurred when both males and females occupied their respective hosts.

Despite this general pattern of reproduction vs. prevalence, $O$. okupa sp. nov. seems to reproduce actively during the whole year, but with an increasing effort during spring-summer and a higher intensity in summer. The absence of ripe females in April 2012 contrasted with the almost $40 \%$ found in 2011 . However, ripe females occurred both before and after April 2012, allowing us to suggest that its absence in April 2012 could have been biased by the low number of symbionts found in this month (Fig. 4; Table 9). Persistent high temperatures can stimulate oocyte growth, subsequently caus- ing the advancement of reproductive period in polychaetes, as reported for the Mediterranean populations of Eupolymnia nebulosa (Montagu, 1819) (Cha et al., 1997). However, our data does not allow assessing whether environmental constraints such as differences in temperature could affect the reproductive cycle of $O$. okupa sp. nov. during the studied period.

\section{Current knowledge on hesionid symbionts}

Thirty out of 170 currently known hesionid species live as commensals of other invertebrates (Martin and Britayev, 1998; Miller and Wolf, 2008; De Assis et al., 2012; Martin et al., 2012, 2015; Britayev et al., 2013; Chim et al., 2013), representing around $18 \%$ of all the known hesionid species and about $6 \%$ of the known symbiotic polychaetes (Table 10). Symbiosis seems to be restricted to the clade Ophiodrominae, which includes the genus Oxydromus. It has multiple origins within the family Hesionidae because Oxydromus and Gyptis, two of its most representative genera with symbiotic species, are not closely related phyllogenetically (Ruta, et al., 2007). Moreover, both are species-rich genera and there is no evidence indicating whether commensalism arose once or multiple times within each of them.

Commensal hesionids are involved in about 65 different associations (Table 10). Except for the polyxenous species of Oxydromus, such as for O. flexuosus (Delle Chiaje, 1827) and O.pugettensis (Johnson, 1901) with up to 10 and 11 hosts, respectively, most symbiotic hesionids are monoxoneus, occurring in only one (15 species) and two (6 species) hosts (Table 10). Hesionid hosts include species from very different taxonomic groups, a variety among symbiotic polychaetes only comparable to that of polynoids (Martin and Britayev, 1998). The most common hosts are, however, echinoderms (particularly starfishes and sea urchins) and polychaetes (Table 10).

Only one genus, Oxydromus, includes symbiotic species living in association with bivalves. These are $O$. pugettensis, O. humesi and O. okupa sp. nov. Although nothing is known on the relationships between $O$. pugettensis and its bivalve host, the polychaete seems to be able to detect at a certain distance the presence of at least two of its host starfishes, P. miniata and Luidia foliolata (Grube, 1866) (Davenport et al., 1960). Also there are some indications of mutualistic behaviour in their relationships with one of its echinoid hosts, the sand dollar Clypeaster humilis (Leske, 1778) (Storch and Niggemann, 1967). The existing analyses of the behaviour of $O$. okupa sp. nov. in experimental condi- 
Table 10. List of the currently known symbiotic species within the family Hesionidae (sensu lato).

\begin{tabular}{|c|c|c|c|c|c|}
\hline SPECIES & AUTHORITY & HOST GROUP & HOST SPECIES & AUTHORITY & SOURCE \\
\hline $\begin{array}{l}\text { Gyptis } \\
\text { ophiocomae }\end{array}$ & $\begin{array}{l}\text { Storch \& } \\
\text { Niggemann, } 1967\end{array}$ & Ophiuroid & $\begin{array}{l}\text { Ophiocoma } \\
\text { scolopendrina }\end{array}$ & (Lamarck, 1816) & Storch and Niggemann, 1967 \\
\hline Gyptis vittata & $\begin{array}{l}\text { Webster \& } \\
\text { Benedict, } 1887\end{array}$ & Polychaete & $\begin{array}{l}\text { Notomastus } \\
\text { lobatus }\end{array}$ & Hartman, 1947 & Gardiner, 1976; Pettibone, 1963 \\
\hline Hesione picta & $\begin{array}{l}\text { Müller in } \\
\text { Grube, } 1858\end{array}$ & Ophiuroid & $\begin{array}{l}\text { Ophionereis } \\
\text { reticulata }\end{array}$ & (Say, 1825) & $\begin{array}{l}\text { De Assis, Bezerra, Brito, } \\
\text { Gondim and Christoffersen, } \\
2012\end{array}$ \\
\hline $\begin{array}{l}\text { Hesionella } \\
\text { mccullochae }\end{array}$ & Hartman, 1939 & Polychaete & $\begin{array}{l}\text { Lumbrineris } \\
\text { brevicirra }\end{array}$ & (Schmarda, 1861) & Hartman, 1939 \\
\hline $\begin{array}{l}\text { Leocrates } \\
\text { chinensis }\end{array}$ & Kinberg, 1866 & Cnidarian & Corals & & Pettibone, 1970 \\
\hline $\begin{array}{l}\text { Leocrates } \\
\text { claparedii }\end{array}$ & $\begin{array}{l}\text { (Costa in } \\
\text { Claparède, 1868) }\end{array}$ & Cnidarian & Corals & & Pettibone, 1970 \\
\hline \multirow[t]{2}{*}{$\begin{array}{l}\text { Microphthalmus } \\
\text { aberrans }\end{array}$} & $\begin{array}{l}\text { (Webster \& } \\
\text { Benedict, 1887) }\end{array}$ & Polychaete & Lysilla alba & Webster, 1879 & Pettibone, 1963 \\
\hline & & Polychaete & $\begin{array}{l}\text { Enoplobranchus } \\
\text { sanguineus }\end{array}$ & (Verrill, 1873) & Pettibone, 1963 \\
\hline $\begin{array}{l}\text { Microphthalmus } \\
\text { hamosus }\end{array}$ & Westheide, 1982 & Sipunculan & $\begin{array}{l}\text { Sipunculus } \\
\text { (Sipunculus) nudus }\end{array}$ & Linnaeus, 1766 & Westheide, 1982 \\
\hline $\begin{array}{l}\text { Microphthalmus } \\
\text { sczelkowii }\end{array}$ & Metschnikow, 1865 & Polychaete & Arenicola marina & (Linnaeus, 1766) & Reise and Ax, 1979 \\
\hline \multirow[t]{4}{*}{$\begin{array}{l}\text { Oxydromus } \\
\text { angustifrons }\end{array}$} & (Grube, 1878) & Asteroid & $\begin{array}{l}\text { Pentaceraster } \\
\text { multispinus }\end{array}$ & (von Martens, 1866) & Jones, 1964 \\
\hline & & Echinoid & $\begin{array}{l}\text { Salmacis } \\
\text { sphaeroides }\end{array}$ & (Linnaeus, 1758) & Chim et al., 2013 \\
\hline & & Echinoid & $\begin{array}{l}\text { Temnopleurus } \\
\text { toreumauticus }\end{array}$ & (Klein, 1778) & Chim et al., 2013 \\
\hline & & Echinoid & Unknown sand dollars & & Mohammad, 1971 \\
\hline \multirow{2}{*}{$\begin{array}{l}\text { Oxydromus } \\
\text { bunbuku }\end{array}$} & (Uchida, 2004) & Echinoid & Brissus agassizii & Döderlein, 1885 & Uchida, 2004 \\
\hline & & Echinoid & Brissus latecarinatus & (Leske, 1778) & Uchida, 2004 \\
\hline \multirow[t]{10}{*}{$\begin{array}{l}\text { Oxydromus } \\
\text { flexuosus }\end{array}$} & $\begin{array}{l}\text { (Delle Chiaje, } \\
\text { 1827) }\end{array}$ & Asteroid & $\begin{array}{l}\text { Astropecten } \\
\text { aranciacus }\end{array}$ & (Linnaeus, 1758) & Barel and Kramers, 1977 \\
\hline & & Asteroid & Astropecten bispinosus & (Otto, 1823) & Barel and Kramers, 1977 \\
\hline & & Asteroid & Astropecten indicus & Döderlein, 1888 & Barel and Kramers, 1977 \\
\hline & & Asteroid & Astropecten irregularis & (Pennant, 1777) & Barel and Kramers, 1977 \\
\hline & & Asteroid & Luidia ciliaris & (Philippi, 1837) & Barel and Kramers, 1977 \\
\hline & & Hemichordata & Balanoglossus sp. & & Clark, 1956 \\
\hline & & Echiuroid & $\begin{array}{l}\text { Maxmuelleria } \\
\text { lankesteri }\end{array}$ & (Herdman, 1897) & Anker et al., 2005 \\
\hline & & Holothuroid & Leptosynapta sp. & & Barel and Kramers, 1977 \\
\hline & & Polychaete & $\begin{array}{l}\text { Neoamphitrite } \\
\text { edwardsi }\end{array}$ & $\begin{array}{l}\text { (Quatrefages, } \\
1866 \text { ) }\end{array}$ & Barel and Kramers, 1977 \\
\hline & & Polychaete & $\begin{array}{l}\text { Euclymene } \\
\text { lombricoides }\end{array}$ & $\begin{array}{l}\text { (Quatrefages, } \\
1866 \text { ) }\end{array}$ & Barel and Kramers, 1977 \\
\hline \multirow{2}{*}{$\begin{array}{l}\text { Oxydromus } \\
\text { herrmanni }\end{array}$} & (Giard, 1882) & Hemichordata & Balanoglossus robinii & Giard, 1882 & Giard, 1882 \\
\hline & & Hemichordata & $\begin{array}{l}\text { Balanoglossus } \\
\text { salmonetus }\end{array}$ & Giard, 1882 & Giard, 1882 \\
\hline $\begin{array}{l}\text { Oxydromus } \\
\text { humesi }\end{array}$ & (Pettibone, 1961) & Bivalve & Tellina nimphalis & Lamarck, 1818 & $\begin{array}{l}\text { Martin et al., 2012; Martin et al., } \\
\text { 2015; Pettibone, } 1961\end{array}$ \\
\hline \multirow[t]{2}{*}{$\begin{array}{l}\text { Oxydromus } \\
\text { okupa } \text { sp. nov. }\end{array}$} & & Bivalve & Scrobicularia plana & (Da Costa, 1778) & $\begin{array}{l}\text { Martin et al., 2012; } \\
\text { Martin et al., 2015, this paper }\end{array}$ \\
\hline & & Bivalve & Macoma cumana & (Costa, 1830) & $\begin{array}{l}\text { Martin et al., 2012; } \\
\text { Martin } \text { et al., 2015, this paper }\end{array}$ \\
\hline $\begin{array}{l}\text { Oxydromus } \\
\text { obscurus }\end{array}$ & (Verrill, 1873) & $\begin{array}{l}\text { Polychaete } \\
\text { Echinoid } \\
\text { Holothuroid }\end{array}$ & $\begin{array}{l}\text { Lysilla alba } \\
\text { Lytechinus } \mathrm{sp} . \\
\text { Thyone } \mathrm{sp} .\end{array}$ & Webster, 1879 & $\begin{array}{l}\text { Pettibone, } 1963 \\
\text { Hartman, } 1951 \\
\text { Pettibone, } 1963\end{array}$ \\
\hline
\end{tabular}


Table 10. cont.

\begin{tabular}{|c|c|c|c|c|c|}
\hline SPECIES & AUTHORITY & HOST GROUP & HOST SPECIES & AUTHORITY & SOURCE \\
\hline $\begin{array}{l}\text { Oxydromus } \\
\text { pallidus }\end{array}$ & Claparède, 1864 & Echiuroid & Lissomyema exilii & $\begin{array}{l}\text { (F. Müller in } \\
\text { Lampert, 1883) }\end{array}$ & Anker et al., 2005 \\
\hline \multirow[t]{11}{*}{$\begin{array}{l}\text { Oxydromus } \\
\text { pugettiensis }\end{array}$} & \multirow[t]{11}{*}{ (Johnson, 1901) } & Asteroid & Patiria miniata & (Brandt, 1835) & $\begin{array}{l}\text { Bartel and Davenport, 1956; } \\
\text { Davenport et al., 1960; Lande } \\
\text { and Reish, 1968; Ricketts et al., } \\
1985\end{array}$ \\
\hline & & Asteroid & Luidia foliolata & (Grube, 1866) & Davenport et al., 1960 \\
\hline & & Asteroid & Luidia magnifica & Fisher, 1906 & Storch and Rosito, 1981 \\
\hline & & Asteroid & Pteraster tesselatus & Ives, 1888 & Storch and Niggemann, 1967 \\
\hline & & Asteroid & Pentaceraster cumingi & (Gray, 1840) & Steinbeck and Ricketts, 1941 \\
\hline & & Asteroid & Pisaster ochraceus & (Brandt, 1835) & $\begin{array}{l}\text { Davenport and Hickok, } 1957 \text {; } \\
\text { Hickok and Davenport, } 1957\end{array}$ \\
\hline & & Asteroid & Luidia foliolata & & Hilbig, 1994; Stewart, 1970 \\
\hline & & Holothuroid & Protankyra bidentata & $\begin{array}{l}\text { (Woodward \& } \\
\text { Barrett, 1858) }\end{array}$ & Okuda, 1936 \\
\hline & & Decapod & Eupagurus sp. & & Hickok and Davenport, 1957 \\
\hline & & Gastropod & Aletes sp. & & Storch and Niggemann, 1967 \\
\hline & & Bivalve & Chama sp. & & Storch and Niggemann, 1967 \\
\hline Oxydromus sp. & & Echinoid & $\begin{array}{l}\text { Linopneustes } \\
\text { longispinus }\end{array}$ & (A. Agassiz, 1878) & $\begin{array}{l}\text { Emson, et al., 1993; } \\
\text { Miller and Wolf, } 2008\end{array}$ \\
\hline \multirow[t]{2}{*}{ Oxydromus sp. 1} & & Asteroid & Luidia maculata & $\begin{array}{l}\text { Müller \& } \\
\text { Troschel, } 1842\end{array}$ & Britayev and Antokhina, 2012 \\
\hline & & Asteroid & Archaster angulatus & $\begin{array}{l}\text { Müller \& } \\
\text { Troschel, } 1842\end{array}$ & Britayev and Antokhina, 2012 \\
\hline \multirow[t]{3}{*}{ Oxydromus sp. 2} & & Asteroid & Luidia maculata & $\begin{array}{l}\text { Müller \& } \\
\text { Troschel, } 1842\end{array}$ & Britayev and Antokhina, 2012 \\
\hline & & Asteroid & Archaster angulatus & $\begin{array}{l}\text { Müller \& } \\
\text { Troschel, } 1842\end{array}$ & Britayev and Antokhina, 2012 \\
\hline & & Asteroid & Archaster typicus & $\begin{array}{l}\text { Müller \& } \\
\text { Troschel, } 1842\end{array}$ & Britayev and Antokhina, 2012 \\
\hline Oxydromus sp. 3 & & Echinoid & $\begin{array}{l}\text { Clypeaster cf. } \\
\text { reticulatus }\end{array}$ & (Linnaeus, 1758) & Britayev and Antokhina, 2012 \\
\hline \multirow[t]{2}{*}{ Oxydromus sp. 4} & & Echinoid & Salmacis bicolor & $\begin{array}{l}\text { L. Agassiz in } \\
\text { L. Agassiz \& } \\
\text { Desor, } 1846\end{array}$ & $\begin{array}{l}\text { Britayev and Antokhina, 2012; } \\
\text { Britayev et al., } 2013\end{array}$ \\
\hline & & Echinoid & $\begin{array}{l}\text { Rhynobrisus } \\
\text { hemiasteroides }\end{array}$ & A. Agassiz, 1879 & Britayev and Antokhina, 2012 \\
\hline $\begin{array}{l}\text { Oxydromus } \\
\text { spinapandens }\end{array}$ & $\begin{array}{l}\text { (Storch \& } \\
\text { Niggemann, 1967) }\end{array}$ & Echinoid & Clypeaster humilis & (Klein, 1778) & Storch and Niggemann, 1967 \\
\hline $\begin{array}{l}\text { Parahesione } \\
\text { luteola }\end{array}$ & (Webster, 1879a) & Decapod & Upogebia affinis & (Say, 1818) & Pettibone, 1956 \\
\hline \multicolumn{2}{|l|}{ Parahesione sp. } & Decapod & Upogebia sp. & & Britayev and Antokhina, 2012 \\
\hline \multirow[t]{2}{*}{$\begin{array}{l}\text { Podarkeopsis } \\
\text { brevipalpa }\end{array}$} & $\begin{array}{l}\text { (Hartmann- } \\
\text { Schröder, 1959) }\end{array}$ & Polychaete & Glycera robusta & Ehlers, 1868 & Gardiner, 1976 \\
\hline & & Holothuroid & Leptosynapta tenuis & (Ayres, 1851) & Gardiner, 1976 \\
\hline \multirow{5}{*}{$\begin{array}{l}\text { Struwela } \\
\text { noodti } \\
\text { Struwela } \mathrm{sp} .\end{array}$} & $\begin{array}{l}\text { Hartmann- } \\
\text { Schröder, } 1959\end{array}$ & Echinoid & Mellita longifissa & Michelin, 1858 & Hartmann-Schröder, 1959 \\
\hline & & Echinoid & Encope grandis & L. Agassiz, 1841 & Campos et al., 2009 \\
\hline & & Echinoid & Encope micropora & L. Agassiz, 1841 & Campos et al., 2009 \\
\hline & & Echinoid & Mellita granti & Mortensen, 1948 & Campos et al., 2009 \\
\hline & & Echinoid & Mellita longifissa & Michelin, 1858 & Campos et al., 2009 \\
\hline
\end{tabular}


tions do not prove the existence of a host-factor in its relationships with $S$. plana, like in the case of $O$. pugettensis and its host starfishes. In turn, the species shows an elaborated and complex host-entering behaviour, which leads the worm to enter inside the host bivalve mainly through the inhalant siphon (Martin et al., 2015). Moreover, the presence of $O$. okupa sp. nov. caused a significant reduction in the soft-body biomass of the infested hosts, compared to the non-infested ones, which may imply affectation of the host's metabolism according to Bierbaum and Ferson (1986) thus leading to a relationship closer to parasitism (Martin et $a l ., 2012$ ). Such a negative influence has been previously reported for other symbiotic polychaetes living in the mantle cavity of bivalves, such as the deep-sea hydrothermal vent polynoids B. seepensis (Britayev et al., 2007). However, contrary to B. seepensis, in the case of O. okupa sp. nov. no damages in the tissues of S. plana were observed (Martin et al., 2012). In B. seepensis, tissue damages were considered as a secondary effect of the worm's feeding inside the host caused by powerful jaws of the polynoid, and not a voluntary ingestion. Oxydromus okupa sp. nov. lacks jaws so that, even in the case of having a feeding mode similar to that $B$. seepensis, the hesionid seems to be able to avoid causing involuntary damage to the host tissues.

Despite the overall growing knowledge on symbiotic hesionids, O. okupa sp. nov. is probably the best known representative of the group to date. Nevertheless, further studies are required to complete the knowledge on this species, which becomes apparent if we compare it with $O$. humesi, with which it shares a similar morphology and a closely related host that is several thousands of kilometres away from Cadiz Bay. In other words, the present study is just another brick in the wall, which hopefully will encourage further research on the complex relationships between the symbiotic species of Oxydromus and their hosts.

\section{Acknowledgments}

The authors would like to thank José Antonio Cuesta and Alberto Arias, from the research group RNM108 of the ICMANCSIC, for their help during sampling and sorting the specimens, and Marta Calleja Julià for contributing to the initial morphometric analyses as a part of her high school practical work at the CEAB. Maria García, from the SEM service at the CEABCSIC, kindly helped with the SEM observations of the specimens. The authors would also like to thank the two anonymous reviewers and the Editors of the journal for their insightful comments, which highly contributed to improve the quality of the manuscript. The 'Parque Natural Bahía de Cádiz' kindly provided sampling facilities. MAM highly acknowledges Pr. Jordi Colomer, his academic tutor at the University of Girona, for the advice and recommendations during the "Treball de Fi de Grau".

This study was funded by the Ministrerio de Educación, Cultura y Deporte (grant number CTM2013-43287-P) and the Agència de Gestió d'Ajuts Universitaris i de Recerca of the Generalitat de Catalunya through the Consolidated Research Group on Marine Benthic Ecology (grant number 2014SGR120) to Daniel Martin, and by the Consejería de Economía, Innovación, Ciencia y Empleo of the Junta de Andalucía, through the Research Group programme of the Plan Andaluz de Investigación Desarrollo e Innovación' (grant number RNM108) to Pilar Drake.

\section{References}

Adams J, Edwards AJ, Emberton H. 1985. Sexual size dimorphism and assortative mating in the obligate coral commensal Trapezia ferruginea Latreille (Decapoda, Xanthidae). Crustaceana 48: 188-194.

Agassiz A. 1878. Report on the results of dredging, under the supervision of Alexander Agassiz, in the Gulf of Mexico, by the U.S. Coast Survey Steamer "Blake", Lieutenant-Commander C.D. Sigsbee, U.S.N., Commanding. Report on the Echini Bulletin of the Museum of Comparative Zoology at Harvard College 5: 181-195.

Agassiz A. 1879. Preliminary report on the Echini of the Exploring Expedition of H.M.S "Challenger". Proceedings of the American Academy of Arts and Sciences, new series 6: 190-212.

Agassiz L. 1841. Monographies d'échinodermes vivans et fossiles. Échinites. Famille des Clypéasteroides. 2 (Seconde Monographie). Neuchâtel, Switzerland: Des Scutelles.

Agassiz L, Desor PJE. 1846. Catalogue raisonné des familles, des genres, et des espèces de la classe des échinodermes. Annales des Sciences Naturelles, Troisième Série, Zoologie 6: 305-374.

Anker A, Murina GV, Lira C, Vera Caripe JA, Palmer AR, Jeng MS. 2005. Macrofauna associated with echiuran burrows: A review with new observations of the innkeeper worm, Ochetostoma erythrogrammon Leuckart and Rüppel, in Venezuela. Zoological Studies 44: 157-190.

Augener H. 1922. Über litorale polychäten von Westindien. Sitzungsberichte der Gesellschaft naturforschender Freunde 1922: 38-53.

Ayres WO. 1851. Descriptions of Holothuria. Proceedings Boston Society Natural History 4: 6-7, 11-12, 25-26, 46-47, 5253, 60-61, 63-64, 69, 70, 143-145, 147-148.

Barel CDN, Kramers PGN. 1977. A survey of the echinoderm associates of the North-East Atlantic area. Zoologische Verhandelingen Leiden 156: 1-159.

Bartel AH, Davenport D. 1956. A technique for the investigation of chemical responses in aquatic animals. British Journal of Animal Behaviour 4: 117-119.

Ben-Eliahu MN. 1987. An approach to nereidid morphometry. Bulletin of the Biological Society of Washington 7: 169-173.

Benjamini Y, Hochberg Y. 1995. Controlling the false discovery rate: a practical and powerful approach to multiple testing. 
Journal of the Royal Statistical Society Series B (Methodological): 289-300.

Bierbaum RM, Ferson SS. 1986. Do symbiotic pea crabs decrease growth rate in mussels? Biological Bulletin Marine Biological Laboratory, Woods Hole 170: 51-61.

Blake JA. 2000. Family Oweniidae Rioja, 1917. In: Blake JA, Hilbig B, Scott PH, eds. Taxonomic atlas of the benthic fauna of the Santa Maria Basin and Western Santa Barbara Channel Volume 7 - The Annelida Part 4 Polychaeta: Flabelligeridae to Sternaspidae. Santa Barbara, California: Santa Barbara Museum of Natural History, 97-127.

Blaxter ML. 2004. The promise of a DNA taxonomy. Philosophical Transactions of the Royal Society of London B. Biological Sciences 359: 669-679.

Brandt JF. 1835. Echinodermata ordo Holothurina. Prodromus Descriptionis Animalium ab H Mertensio in Orbis Terrarum Circumnavigatione Observatorum. Petropoli, 42-62.

Britayev TA. 1991. Life cycle of the symbiotic scale-worm Arctonoe vittata (Polychaeta: Polynoidae). In: Systematics, biology and Morphology of World Polychaeta. Proceedings of the Second International Polychaeta Conference. Ophelia Supplement 5: 305-312.

Britayev TA, Antokhina TI. 2012. Symbiotic polychaetes of from Nhatrang Bay, Vietnam. In: Britayev TA, Pavlov DS, eds. Benthic fauna of the Bay of Nhatrang, Southern Vietnam. Moscow: KMK Scientific Press Ltd., 11-54.

Britayev TA, Fahrutdinov RR. 1994. Pontoniin shrimps associated with molluscs at the coast of South Vietnam [In Russian]. In: Pavlov DS, Sbikin JN, eds. Hydrobionts of South Vietnam. Moscow: Nauka, 128-145.

Britayev TA, Zamyshliak EA. 1996. Association of the commensal scaleworm Gastrolepidia clavigera (Polychaeta: Polynoidae) with holothurians near the coast of South Vietnam. Ophelia 45: 175-190.

Britayev TA, Smurov AV, Adrianov AV, Bazhin AG, Rhzavsky AV, Sveshnicov VA. 1989. Ecology of the symbiotic polychaete Arctonoe vittata according to the peculiarities of the ecology of the starfish Asterias ratbunae. [In Russian]. Symbiosis among marine animals. Moscow: A.N. Severtzov Institute, Russian Academy of Sciences, 102-127.

Britayev TA, Martin D, Krylova EM, von Cosel R, Aksiuk ES. 2007. Life-history traits of the symbiotic scale-worm Branchipolynoe seepensis and its relationships with host mussels of the genus Bathymodiolus from hydrothermal vents. Marine Ecology: An Evolutionary Perspective 28: 36-48.

Britayev TA, Bratova OA, Dgebuadze PY. 2013. Symbiotic assemblage associated with the tropical sea urchin, Salmacis bicolor (Echinoidea: Temnopleuridae) in the An Thoi archipelago, Vietnam. Symbiosis 61:155-161. http://dx.doi.org/10.1007/s13199-013-0263-x

Campos E, de Campos A, León-González JAd. 2009. Diversity and ecological remarks of ectocommensals and ectoparasites (Annelida, Crustacea, Mollusca) of echinoids (Echinoidea: Mellitidae) in the Sea of Cortez, Mexico. Parasitology Research 105: 479-487. http://dx.doi.org/10.1007/s00436-009-1419-8

Cargnin-Ferreira E. 2005. Evaluación de la contaminación metálica en una población de Scrobicularia plana del Caño Sancti Petri. Doctoral Thesis. Universidad de Cádiz.

Cha JH, Martin D, Bhaud M. 1997. Effects of temperature on oocyte growth in the Mediterranean terebellid Eupolymnia nebulosa (Annelida, Polychaeta). Marine Biology 128: 433439.

Carvalho S, Constantino R, Cerqueira M, Pereira F, Subida MD, Drake P, Gaspar MB. 2013. Short-term impact of bait digging on intertidal macrobenthic assemblages of two south Iberian Atlantic systems. Estuarine, Coastal and Shelf Science 132:65-76. http://dx.doi.org/10.1016/j.ecss.2011.06.017

Chim CK, Ong JJL, Tan KS. 2013. An association between a hesionid polychaete and temnopleurid echinoids from Singapore. Cahiers de Biologie Marine 54: 577-585.

Claparède É. 1864. Glanures zootomiques parmi les annélides de Port-Vendres (Pyrénées Orientales). Mémoires de la Société de Physique et d'Histoire Naturelle de Genève 17: 463600, pls. 461-468.

Claparède É. 1868. Les Annélides Chétopodes du Golfe de Naples. Mémoires de la Société de Physique et d'Histoire Naturelle de Genève 19: 313-584.

Clark RB. 1956. Capitella capitata as a commensal, with a bibliography of parasitism and commensalism in the polychaetes. Annals and Magazine of Natural History 12: 433448.

Clarke KR, Gorley RN. 2006. PRIMER v6: user manual/tutorial (Plymouth routines in multivariate ecological research). Plymouth: PRIMER-E Ltd.

Clarke KR, Warwick RM. 2001. Change in marine community: An approach to statistical analysis and interpretation. 2nd Edition. Plymouth: PRIMER-E Ltd.

Costa OG. 1830. Catalogo sistematico e ragionato de' testacei delle Due Sicilie. Napoli: Tipografia della Minerva.

Coutinho MCL, Paiva PC, Santos CSG. 2015. Morphometric analysis of two sympatric species of Perinereis (Annelida: Nereididae) from the Brazilian coast. Journal of the Marine Biological Association of the United Kingdom 95: 953-959. http://dx.doi.org/10.1017/S0025315415000247

Culurgioni J, D’Amico V, Coluccia E, Mulas A, Figus V. 2006. Metazoan parasite fauna of conger eel Conger conger L. from Sardinian waters (Italy). Ittiopatologia 3: 253-261.

Da Costa EM. 1778. Historia Naturalis Testaceorum Britanniae or The British Conchology; containing the description and other particulars of Natural History of the shells of Great Britain and Ireland. London: Millan. White, Elmsley \& Robson.

Davenport D, Boolootian RA. 1966. Echinoderms and the control of behavior in associations. Physiology of Echinodermata. New York: Academic PressJohn Wiley and Sons, 145156.

Davenport D, Hickok JF. 1957. Notes on the early stages of the facultative commensal Podarke pugettensis (Polychaeta, Hesionidae). Annals and Magazine of Natural History 10: 625631.

Davenport D, Camougis G, Hickok JF. 1960. Analysis of the behaviour of commensals in host-factor. I. A hesionid polychaete and pinnotherid crab. Animal Behaviour 8: 209-218.

De Assis JE, Bezerra EAS, Brito RJ, Gondim Ai, Christoffersen ML. 2012. An association between Hesione picta (Polychaeta: Hesionidae) and Ophionereis reticulata (Ophiuroidea: Ophionereididae) from the Brazilian coast. Zoological Studies 51: 762-767.

Delle Chiaje S. 1827. Memorie sulla storia e notomia degli animali senza vertebre del Regno di Napoli. Napoli: Stamperia della Società Tipografica. 
Döderlein L. 1885. Seeigel von Japan und den Liu-Kiu Inseln. Archiv für Naturgeschichte 51: 73-112.

Döderlein L. 1888. Echinodermen von Ceylon. Bericht über die von den Herren Dres Sarasin gesammelten Asteroidea, Ophiuroidea und Echinoidea. Zoologische Jahrbücher, Abtheilung für Systematik, Geographie und Biologie der Thiere 3: 821-846.

Drake P, Marco-Herrero H, Subida MD, Arias AM, Cuesta JA. 2014. Host use pattern of the pea crab Afropinnotheres monodi: potential effects on its reproductive success and geographical expansion. Marine Ecology Progress Series 498: 203-215. http://dx.doi.org/10.3354/meps10623

Duchassaing P., Michelotti G. 1864. Spongiaires de la mer Caraibe. Livres 1-2. Natuurkundige verhandelingen van de Hollandsche Maatschappij der Wetenschappen te Haarlem 2122:1-124, $25 \mathrm{pl}$.

Ehlers E. 1868. Die Borstenwürmer (Annelida Chaetopoda) nach systematischen und anatomischen Untersuchungen dargestellt. Leipzig: Wilhelm Engelmann.

Eisig H. 1906. Ichthyotomus sanguinarius, eine auf Aalen schmarotzende Annelide. Fauna und Flora des Golfes von Neapel 28: 1-300.

Emson RH, Young CM, Paterson GLJ. 1993. A fire worm with a sheltered life: studies of Benthoscolex cubanus Hartman (Amphinomidae), an internal associate of the bathyal seaurchin Archeopneustes hystrix (A. Agassiz, 1880). Journal of Natural History 27: 1010-1028.

Fauchald K. 1991. A morphometric study of eunicid polychaetes from Belize, western Caribbean Sea. Ophelia Supplement 5: 47-54.

Fisher WK. 1906. The starfishes of the Hawaiian Islands: US Government Printing Office.

Ford E, Hutchings P. 2005. An analysis of morphological characters of Owenia useful to distinguish species: description of three new species of Owenia (Oweniidae: Polychaeta) from Australian waters. Marine Ecology 26: 181-196. http://dx.doi.org/10.1111/j.1439-0485.2005.00062.x

Forskål P. 1775. Descriptiones Animalium - Avium, amphiborum, insectorum, vermium qua in itinere orientali observavit Petrus Forskal, post mortem auctoris edidit Carsten Niebuhr. Kobenhavn.

Gardiner SL. 1976. Errant Polychaete Annelids from North Carolina. The Journal of the Elisha Mitchell Scientific Society 91: 77-220.

Garraffoni ARS, de Garcia Camargo M. 2006. First application of morphometrics in a study of variations in uncinial shape present within the Terebellidae (Polychaeta). Zoological Studies 45: 75-80.

Giard MA. 1882. Sur un type synthétique d'annélide (Anoplonereis herrmanni) commensal des Balanoglossus. Comptes Rendues hebdomadaires des séances de l'Academie des Sciences, Paris 95: 389-391.

Gilpin-Brown JB. 1969. Host-adoption in the commensal polychaete Nereis fucata. Journal of the Marine Biological Association of the United Kingdom 49: 121-127.

Giribet G. 2015. Morphology should not be forgotten in the era of genomics - a phylogenetic perspective. Zoologischer Anzeiger - A Journal of Comparative Zoology 256: 96-103.

Glasby CJ, Glasby TM. 2006. Two types of uncini in Polycirrus (Polychaeta: Terebellidae: Polycirrinae) revealed using geo- metric morphometrics. Journal of Natural History 40: 237253.

Gmelin JF. 1791. Vermes. In: Gmelin J.F. (Ed.) Caroli a Linnaei Systema Naturae per Regna Tria Naturae, Editio Decima Tertia, Aucta Reformata. Tome 1, Pars 6 (Vermes). G.E. Beer, Lipsiae [Leipzig]. pp. 3021-3910.

Godfray H. 2007. Linnaeus in the information age. Nature 446: 259-260.

Gravier C. 1900. Contribution à l'étude des Annélides Polychètes de la Mer Rouge. Première partie. Nouvelles Archives du Museum d'Histoire Naturelle Paris 2: 137-282.

Gray JE. 1828. Mollusca. Original figures and short systematic descriptions of new and unfigured animals. Spicilegia Zoologica Part 1 1: 3-7, pls 1, 2, 5.

Gray JE. 1840. A synopsis of the genera and species of the class Hypostoma (Asterias Linnaeus). Annals of the Magazine of Natural History 6: 175-184; 275-290.

Grube AE. 1850. Die Familien der Anneliden. Archiv fur Naturgeschichte, Berlin 16: 249-364.

Grube AE. 1855. Beschreibungen neuer oder wenig bekannter Anneliden. Archiv fur Naturgeschichte, Berlin 21: 81-136, pls. 133-135.

Grube AE. 1858. Einiges über die Annelidenfauna der Insel Santa Catharina an der brasilianischen Küste. Archiv fur Naturgeschichte, Berlin 24: 211-220.

Grube AE. 1866. Einige neue Seesterne des hiesigen zoologischen Museums. Jahresbericht der Schlesiches Gesellschaft fur vaterlandische Cultur 43: 59-61.

Grube AE. 1878. Annulata Semperiana. Beiträge zur Kenntniss der Annelidenfauna der Philippinen. Mémoires de L'Academie Imperiale des Sciences de St Petersbourg, série 725 : 1-300, pls. 319.

Hartman O. 1939. New species of polychaetous annelids from southern California. With a discussion on the host of one of them. Allan Hancock Pacific Expeditions 7: 157-172.

Hartman O. 1947. Polychaetous annelids. Part VII. Capitellidae. Allan Hancock Pacific Expeditions 10: 391-481.

Hartman O. 1951. The littoral marine Annelids of the Gulf of Mexico. Publications of the Institute of Marine Sciences 2: 7-124.

Hartmann-Schröder G. 1959. Zur Ökologie der Polychaeten des Mangrove-Estero-Gebietes von El Salvador. Beiträge zur Neotropischen Fauna 1: 69-183.

Hebert PD, Gregory TR. 2005. The promise of DNA barcoding for taxonomy. Systematic Biology 54: 852-859.

Hendler G, Meyer DL. 1982. An association of a polychaete, Branchiosyllis exilis, with an ophiuroid, Ophiocoma echinata, in Panama. Bulletin of Marine Science 32: 736-744.

Herdman WA. 1897. Note on a new British echiuroid gephyrean, with remarks on the genera Thalassema and Hamingia. Quarterly Journal of Microscopical Science New Series 40: 367-384.

Hernández-Alcántara P, Solís-Weiss V. 2014. Anatomical and morphometric analysis of a new species of Leitoscoloplos (Annelida Orbiniidae) with numerous stomach papillae, from the Gulf of California, Eastern Pacific. Contributions to Zoology 83: 133-150.

Hickok JF, Davenport D. 1957. Further studies in the behavior of commensal polychaetes. Biological Bulletin Marine Biological Laboratory, Woods Hole 113: 397-406.

Hilbig B. 1994. Volume 4 - The Annelida Part 1. 9. Family Hes- 
ionidae Sars, 1862. In: Blake JA, Hilbig B, eds. Taxonomic atlas of the benthic fauna of the Santa Barbara Basin and western Santa Barbara Channel. Santa Barbara: Santa Barbara Museum of Natural History, 243-269.

Hobbs J-P, Munday P. 2004. Intraspecific competition controls spatial distribution and social organisation of the coraldwelling goby Gobiodon histrio. Marine Ecology Progress Series 278: 253-259.

Huberty CJ. 1994. Applied discriminant analysis. New York (USA): John Wiley and Sons.

Ives JE. 1888. On two new species of starfishes. Proceedings of the Academy of Natural Sciences of Philadelphia 40: 421424.

Johnson HP. 1901. The Polychaeta of the Puget Sound region. Proceedings of the Boston Society for Natural History 29: 381-437, pls. 319.

Jones S. 1964. Notes on animal associations. 4. The starfish Pentaceros hedemanni (Lutken) and the hesionid polychaete $P o$ darke angustifrons (Grube). Journal of the Marine Biological Association of India 6: 249-250.

Kinberg JGH. 1866. Annulata nova. Öfversigt af Kongliga Vetenskaps-Akademiens Förhandlingar, Stockholm 22: 239258.

Klein JT. 1778. Jacobi Theodori Klein Naturalis dispositio echinodermatum. Accesserunt Lucubratiuncula de aculeis echinorum marinorum et Spicilegium de belemnitis. Edita et descriptionibus novisque inventis et synonymis auctorum aucta a Nathanaele Godofredo Leske. Lipsae: Ex Officina Gleditschiana.

Koh BS, Bhaud M. 2003. Identification of new criteria for differentiating between populations of Owenia fusiformis (Annelida, Polycheta) from different origins; rehabilitation of old species and erection of two new species. Vie et Milieu 53: 65-96.

Koh BS, Bhaud M, Jirkov IA. 2003. Two new species of Owenia (Annelida: Polychaeta) in the northern part of the North Atlantic Ocean and remarks on previously erected species from the same area. Sarsia 88: 175-188.

Lamarck JB. 1816. Ordre Second. Radiaires Échinodermes. Histoire Naturelle des Animaux sans Vertèbres 2: 522-568.

Lamarck JB. 1818. Histoire naturelle des Animaux sans Vertèbres, présentant les caractères généraux et particuliers de ces animaux, leur distribution, leurs classes, leurs familles, leurs genres, et la citation des principales espèces qui s'y rapportent; précédée d'une introduction offrant la détermination des caractères essentiels de l'animal, sa distinction du végétal et des autres corps naturels, enfin, l'exposition des principes fondamentaux de la zoologie. Vol. 5. Paris: Déterville \& Verdière.

Lampert K. 1883. Über einige neue Thalassemen. Zeitschrift für wissenschaftliche Zoologie 39: 334-342.

Lande R, Reish DJ. 1968. Seasonal occurence of the commensal polychaetous annelid Ophiodromus pugettensis on the starfish Patiria miniata. Bulletin of the Southern California Academy of Sciences 67: 104-111.

Lattig P, San Martín G, Martin D. 2007. Taxonomic and morphometric analyses of the Haplosyllis spongicola complex (Polychaeta: Syllidae: Syllinae) from Spanish seas, with redescription of the type species and descriptions of two new species. Scientia Marina 71: 551-570.

Leske NG. 1778. Additamenta ad Jacobi Theodori Keeini natu- ralem Dispositionem Echinodermatum et Lucubratiunculam de Aculeis Echinorum marinorum. Lipsiae: Gleditsch.

Linnaeus C. 1758. Systema Naturae per Regna Tria Naturae, Secundum Classes, Ordines, Genera, Species, cum characteribus, differentiis, synonymis, locis. Tomus I. Editio Decima, Reformata. Stockholm: Laurentii Salvii.

Linnaeus C. 1766. Systema Naturae per Regna Tria Naturae, Secundum Classes, Ordines, Genera, Species, cum characteribus, differentiis, synonymis, locis. Tomus I. Editio Duodecima, Reformata. Stockholm: Laurentii Salvii.

Linnaeus C. 1767. Systema Naturae per Regna Tria Naturae, Editio Duodecima, Reformata, Tomus I, Pars II. Regnum Animale. Stockholm: Laurentii Salvii.

Lütken CF. 1871. Fortsatte kritiske org beskrivende Bidrag til Kundskab om Sostjernerne (Asteriderme). Videnskabelige Meddelelser fra den naturhistoriske Forening i Kjøbenhavn 1871: 227-308.

Martin D, Britayev TA. 1998. Symbiotic polychaetes: Review of known species. Oceanography and Marine Biology: An Annual Review 36: 217-340.

Martin D, Abelló P, Cartes J. 1991. A new species of Ophryotrocha (Polychaeta: Dorvilleidae) commensal in Geryon longipes (Crustacea: Brachyura) from the Western Mediterranean Sea. Journal of Natural History 25: 279-291.

Martin D, Rosell D, Uriz MJ. 1992. Harmothoe hyalonemae sp. nov. (Polychaeta, Polynoidae), an exclusive inhabitant of different Atlanto-Mediterranean species of Hyalonema (Porifera, Hexactinellida). Ophelia 35: 169-185.

Martin D, Britayev TA, San Martín G, Gil J. 2003. Inter-population variability and character description in the sponge associated Haplosyllis spongicola complex (Polychaeta: Syllidae). Hydrobiologia 496: 145-162.

Martin D, Koh BS, Bhaud M, Gil J, Dutrieux É. 2006. The genus Owenia (Annelida, Polychaeta) in the Persian Gulf, with description of a new species, Owenia persica. Organisms Diversity and Evolution 6: 325-326.

Martin D, Aguado MT, Britayev TA. 2009. Review of the symbiotic genus Haplosyllides, with description of a new species. Zoological Science 26: 646-655.

Martin D, Cuesta JA, Drake P, Gil J, Pleijel F. 2012. The symbiotic hesionid Parasyllidea humesi Pettibone, 1961 (Annelida: Polychaeta) hosted by Scrobicularia plana (da Costa, 1778) (Mollusca: Bivalvia: Semelidade) in European waters. Organisms Diversity \& Evolution 12: 145-153. http://dx.doi.org/10.1007/s13127-012-0086-2

Martin D, Nygren A, Hjelmstedt P, Drake P, Gil J. 2015. On the enigmatic symbiotic polychaete "Parasyllidea" humesi Pettibone, 1961 (Hesionidae): taxonomy, phylogeny and behaviour. Zoological Journal of the Linnean Society 174: 429-446. http://dx.doi.org/10.1111/zoj.12249

McIntosh WC. 1885. Report on the Annelida Polychaeta collected by the H.M.S. Challenger during the years 1873-1876. Report on the Scientific Results of the Voyage of HMS Challenger during the years 1872-76 12: 1-554.

Metschnikow E. 1865. Beiträge zur Kenntniss der Chaetopoden. Zeitschrift für wissenschaftliche Zoologie Leipzig, 15: 328341, pls. 324-325.

Michelin H. 1858. Revue des espèces connues et nouvelles du genre Mellita, famille des clypéastroides. Revue et Magazine de Zoologie 2: 358-364.

Miller W, Wolf M. 2008. Crawling with worms: a look at two 
symbiotic relationships between polychaetes and urchins from the Bahamas. University of Oregon Scholars' Bank. Oregon: University of Oregon. p 1-10. https://scholarsbank. uoregon.edu/dspace/handle/ 1794/6875.

Mohammad MBM. 1971. Intertidal polychaetes from Kuwait, Arabian Gulf, with descriptions of three new species. Journal of Zoology, London 163: 285-303.

Montagu G. 1819. Descriptions of five British species of the genus Terebella. Transactions of the Linnean Society of London 12: 340-344, pl. 311-313.

Mortensen T. 1948. New Echinoidea (Cassiduloida, Clypeasteroida). Preliminary notice. Videnskabelige Meddelelser fra Dansk naturhistorisk Forening i Kфbenhavn 111: 67-72.

Müller JX, Troschel FH. 1842. System der Asteriden. Braunschweig: Friedrich: Vieweg.

Müller OF. 1776. Zoologicae Danicae Prodromus, seu Animalium Daniae et Norvegiae indigenarum characteres, nomina et synonyma imprimis popularium. Havniae [Copenhagen]: Hallageriis.

Okuda S. 1936. Description of two polychaetous annelids found in burrows of an apodous holothurian. Annotations on Zoology, Japan 15: 410-415.

Orrhage L, Sundberg P. 1990. Multivariate analysis of morphometric differentiation within the Laonice cirrata-group (Polychaeta, Spionidae). Zoologica Scripta 19: 173-178.

Otto AW. 1823. Beschreibung einiger neueu Mollusken und Zoophyten. Nova acta Academiae Caesareae Leopoldino-Carolinae Germanicae Naturae Curiosorum 11: 273-314.

Padial JM, Miralles A, De la Riva I, Vences M. 2010. The integrative future of taxonomy. Frontiers in Zoology 7: 1.

Pennant T. 1777. British Zoology. Warrington: William Eyres, for Benjamin White.

Pettibone MH. 1956. Some polychaete worms of the families Hesionidae, Syllidae, and Nereidae from the coast of North America, West Indies, and Gulf of Mexico. Journal of the Washington Academy of Sciences 46: 281-294.

Pettibone MH. 1961. New species of polychaete worms from the Atlantic Ocean, with a revision of the Dorvilleidae. Proceedings of the Biological Society of Washington 74: 167-186.

Pettibone MH. 1963. Marine polychaete worms of the New England region. Part 1. Families Aphroditidae through Trochochaetidae. Bulletin of the United States National Museum 227: 1-356.

Pettibone MH. 1970. Polychaeta Errantia of the Siboga Expedition. Part IV. Some additional polychaetes of the Polynoidae, Hesionidae, Nereidae, Goniadidae, Eunicidae, and Onuphidae, selected as new species by the late Dr. Hermann Augener with remarks on other related species. Siboga-Expeditie Uitkomsten op Zoologisch, Bonatisch, Oceanographisch en Geol ogisch gebied verzameld in Nederlandsch Oost-Indie 1899-1900. Leiden: E.J. Brill, 24: 199-270.

Pettibone MH. 1986. A new scale worm commensal with deepsea mussels in the seep-sites at the Florida Escarpment in the Eastern Gulf of Mexico (Polychaeta: Polynoidae: Branchipolynoidae). Proceedings of the Biological Society of Washington 99: 444-451.

Philippi RA. 1837. Ueber die mit Asterias aurantiaca verwandten und verwechselten Asterien der sicilianschen Küste. Archiv für Naturgeschichte 3: 193-194.

Quatrefages Ad. 1866. Histoire naturelle des Annelés marins et d'eau douce. Annélides et Géphyriens. Volume 2. Première et Deuxième Parties. Paris: Librarie Encyclopédique de Roret.

Reise K, Ax P. 1979. A meiofaunal "thiobios" limited to the anaerobic sulfide system of marine sand does not exist. Marine Biology 54: 225-237.

Ricketts EF, Calvin J, Hedgpeth JW, Phillips DW. 1985. Between Pacific tides. Stanford: Stanford University Press.

Rozbaczylo N, Cañete JI. 1993. A new species of scale-worm, Harmothoe commensalis (Polychaeta: Polynoidae), from mantle cavities of two Chilean clams. Proceedings of the Biological Society of Washington 106: 666-672.

Ruta C, Nygren A, Rousset V, Sundberg P, Tillier A, Wiklund H, Pleijel F. 2007. Phylogeny of Hesionidae (Aciculata, Polychaeta), assessed from morphology, 18S rDNA, 28S rDNA, 16S rDNA and COI. Zoologica Scripta 36: 99-107. http://dx.doi.org/10.1111/j.1463-6409.2006.00255.x

Santos S, Luttikhuizen PC, Campos J, Heip CHR, van der Veer HW. 2011. Spatial distribution patterns of the peppery furrow shell Scrobicularia plana (da Costa, 1778) along the European coast: A review. Journal of Sea Research 66: 238247. http://dx.doi.org/10.1016/j.seares.2011.07.001

Say T. 1818. An account of the Crustacea of the United States, part 5. Journal of the Academy of Natural Sciences at Philadelphia 1: 235-253.

Say T. 1825. On the species of the Linnaean genus Asterias inhabiting the coast of the U.S. Journal of the Academy of Natural Sciences of Philadelphia 5: 141-154.

Schmarda LK. 1861. Neue wirbellose Thiere beobachtet und gesammelt auf einer Reise un die Erdr 1853 bis 1857. Erster Band (zweite halfte) Turbellarian, Rotatorien un Anneliden. Leipzig: Wilhelm Engelmann.

Sigvaldadóttir E, Mackie ASY. 1993. Prionospio steenstrupi, P. fallax and P. dubia (Polychaeta, Spionidae): re-evaluation of identity and status. Sarsia 78: 203-219.

Spengler L. 1798. Over det toskallede Slægt Tellinerne. Skrivter af Naturhistorie-Selskabet, Kiфbenhavn 4: 67-121.

Steinbeck J, Ricketts EF. 1941. Sea of Cortez. A leisurely journal of travel and research. With a scientific appendix comprising materials for a source book on the marine animals of the Panamic faunal province. New York: Viking Press.

Stewart WC. 1970. A study of the nature of the attractant emitted by the asteroid host of the commensal polychaete Ophiodromus pugettiensis $\mathrm{PhD}$. University of California.

Storch V, Niggemann R. 1967. Auf Echinodermen lebende Polychaeten. Kieler Meeresforschungen 23: 156-164.

Storch V, Rosito RM. 1981. Polychaetes from interespecific associations found off Cebu. The Philippine Scientist 18: 1-9.

Subida MD, Arias AM, Drake P, García Raso E, Rodríguez A, Cuesta JA. 2011. On the occurrence of Afropinnotheres monodi Manning, 1993 (Decapoda: Pinnotheridae) in European waters. Journal of Crustacean Biology 31: 367-369.

Subida MD, Berihuete A, Drake P, Blasco J. 2013. Multivariate methods and artificial neural networks in the assessment of the response of infaunal assemblages to sediment metal contamination and organic enrichment. Science of The Total Environment 450-451: 289-300.

Summers M, Pleijel F, Rouse GW. 2015. Whale falls, multiple colonisations of the deep, and the phylogeny of Hesionidae (Annelida). Invertebrate Systematics 29:105-123. http://dx.doi.org/10.1071/IS14055

Sundet J, Jobling M. 1985. An investigation of the interactions 
between the nemertine, Malacobdella grossa, and its bivalve host, Arctica islandica. In: Gray JS, and Christiansen ME, eds. Marine biology of polar regions and effects of stress on marine organisms. Oslo: University of Oslo, 185-197.

Uchida H. 2004. Hesionidae (Annelida, Polychaeta) from Japan. I. Kuroshio Biosphere 1: 27-92.

Valenciennes A. 1837. Tome douzième. In: Cuvier G, Valenciennes A, eds. Histoire naturelle de poissons. Strasbourg: Levrault

Verrill AE. 1873. Report upon the invertebrate animals of Vineyard Sound and the adjacent waters, with an account of the physical characters of the region. Report of the United States Commission for Fisheries 1871-72: 295-778.

Verrill AE. 1909. Descriptions of new genera and species of starfishes from North Pacific Coast of America. American Journal of Science 28: 59-70.

von Martens E. 1866. Ueber ostasiatische Echinodermen. Archiv für Naturgeschichte 32:133-189.

Webster HE. 1879. The Annelida Chaetopoda of New Jersey. Annual Reports of the New York State Museum of Natural
History 32: 101-128.

Webster HE, Benedict JE. 1887. The Annelida Chaetopoda, from Eastport, Maine. Annual Report of the United States Commission of Fish and Fisheries, Washington 1885: 707-758.

Westheide W. 1982. Microphthalmus hamosus sp. n. (Polychaeta, Hesionidae) - an example of evolution leading from the interstitial fauna to a macrofaunal interspecific relationship. Zoologica Scripta 11: 189-193.

Will KW, Mishler BD, Wheeler QD. 2005. The perils of DNA barcoding and the need for integrative taxonomy. Systematic Biology 54: 844-851.

Woodward SP, Barrett L. 1858. On the genus Synapta (communicated by Gaskoin, J. S.). Proceedings of the Zoological Society of London 26: 360-367.

Received: 16 November 2016

Revised and accepted: 28 March 2017

Published online: 23 October 2017

Editor: B.W. Hoeksema 


\section{Appendix}

In this section, the specimens of Oxydromus living symbiotically with the tellinid bivalves Scrobicularia plana and Macoma cumana in the Atlantic coasts of the Iberian Peninsula are described as a new species. The new species was previously confused with the congeneric Oxydromus humesi, which also lives symbiotically with a tellinid bivalve, Tellina nymphalis, in Congolese Atlantic coasts. To allow comparisons, a morphometric diagnosis of $O$. humesi and a general morphological and morphometric descriptions of the new species are provided. The type series of the two species are deposited at the Smithsonian Museum (USNM), the Museo nacional de Ciencias Naturales of Madrid (MNCN), the Annelida Polychaeta research collection of the Centre d'Estudis Avançats de Blanes (CEAB.A.P.), the Museu Nacional de História Natural e da Ciência of Lisboa (MUHNAC), the Biological Research Collection of the Departamento de Biologia of the Universidade de Aveiro (DBUA), the Senckenberg Forschungsinstitut und Naturmuseum of Frankfurt (SMF) and the National Museum of Wales, Cardiff (NMW).

\section{Taxonomic account}

Family Hesionidae Grube, 1850

Genus Oxydromus Grube, 1855

Oxydromus humesi (Pettibone, 1961)

LSID: urn:Isid:zoobank.org:act: 8453A918-89A8-4EEB-B78D-F9C452A39FA5

Parasyllidea humesi Pettibone, 1961. Pettibone (1961): figs. 4a-4h.

Oxydromus humesi (Pettibone, 1961). Martin et al. (2015) 434-441, figs. 4 (A, C, E), 5 (C, D, E, H) - 6 (A, C) -7 .

Material examined. Paratypes: USNM 30012, ca. 50 specimens fixed in formalin and preserved in $70 \%$ ethanol, Loango, Republic of Congo. (West Africa, approximately $4^{\circ} 37^{\prime} 42.6$ ", $11^{\circ} 49^{\prime} 30.0$ "); intertidal, mangrove muddy bottoms.

Morphometric diagnosis. Based on the average proportions being significant different from O. okupa sp. nov. (Table 8); "long" and "short" refer to parapodia of chaetigers 10 and 15, bearing long and short cirrostyles, respectively. General morphological description same as $O$. okupa sp. nov. Ratios number of segment and body width (without parapodia) vs. body width (with parapodia) ca. 0.03 and 0.5 , respectively. Lateral antennae, palpophores and palpostyles ca. $0.5,0.25$ and 0.4 as long as prostomium length, respectively. Distance between anterior and posterior eyespots ca. 0.21 as long as prostomium length. Distance between anterior eyespots ca. 1.06 as long as that between posterior ones. Long and short dorsal cirrostyles 9 and 8 as long as cirrophores and 1.5 and 1.2 as long as dorsal lobes, respectively. Ventral lobe twice as long as dorsal one. Serration near blade tip less than twice short as blade width.

Oxydromus okupa Martin, Meca and Gil sp. nov.

LSID: urn:lsid:zoobank.org:pub:

D97B28C0-4BE9-4C1E-93F8-BD78F994A8D1

Figures 7-9

Parasyllidea humesi [non Pettibone, 1961]. Martin et al. (2012): 147-148, fig. 2b-2c;

Oxydromus humesi [non (Pettibone, 1961)]. Martin et al. (2015): 434-441, figs. 3, 4 (B, D, F), 5 (A, B, F, G), 6 (B, D), 7.

Material examined: Holotype MNCN 16.01/17760, 1 specimen. Paratypes: MNCN 16.01/17761, 24 specimens. Collected at Río San Pedro (Cádiz Bay, southern Atlantic coast of the Iberian Peninsula, 36 31'56.28", $\left.6^{\circ} 12 ' 53.28^{\prime \prime}\right)$, intertidal muddy bottoms. All specimens fixed in a $4 \%$ formalin-seawater solution and preserved in $70 \%$ ethanol.

Additional material: Paratypes: MNCN 16.01/16090, 20 specimens, and CEAB.A.P. 854 A, 20 specimens. MUHNAC, MB29-000343 to MB29-000357, 15 specimens; DBUA0002020.01 to DBUA0002020.13, 13 specimens; SMF 24348 to SMF 24353, 6 specimens; NMW.Z.2017.010.0001 to NMW.Z.2017.010.0006, 9 specimens. Collection, fixation and preservation as for holotype.

General morphological description: Body rusty orange to tan (pale yellowish when preserved), flattened dorsoventrally, tapering gradually posteriorly. Prostomium subrectangular, without posterior incisions, with two 


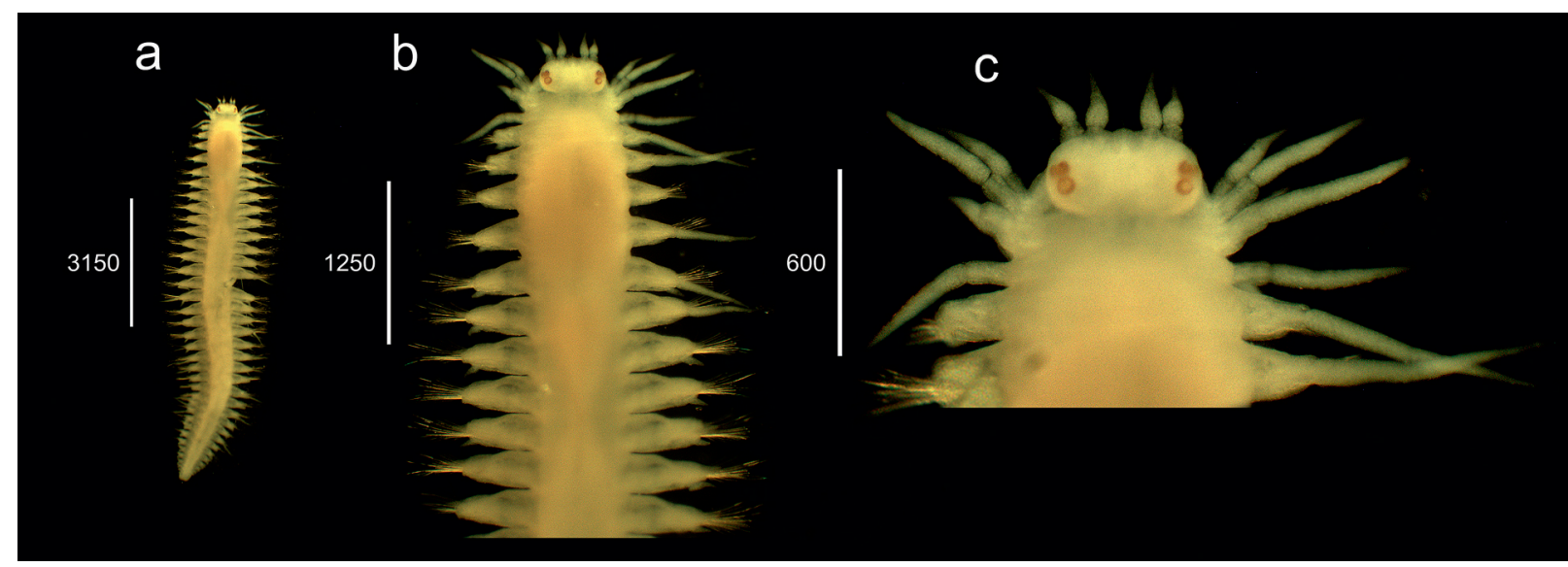

Fig. 7. Oxydromus okupa sp. nov. Light microscopy micrographs of the holotype in dorsal view. a. Whole worm. b. Anterior mid-body. c. Anterior end. Scale bars are $\mu \mathrm{m}$.

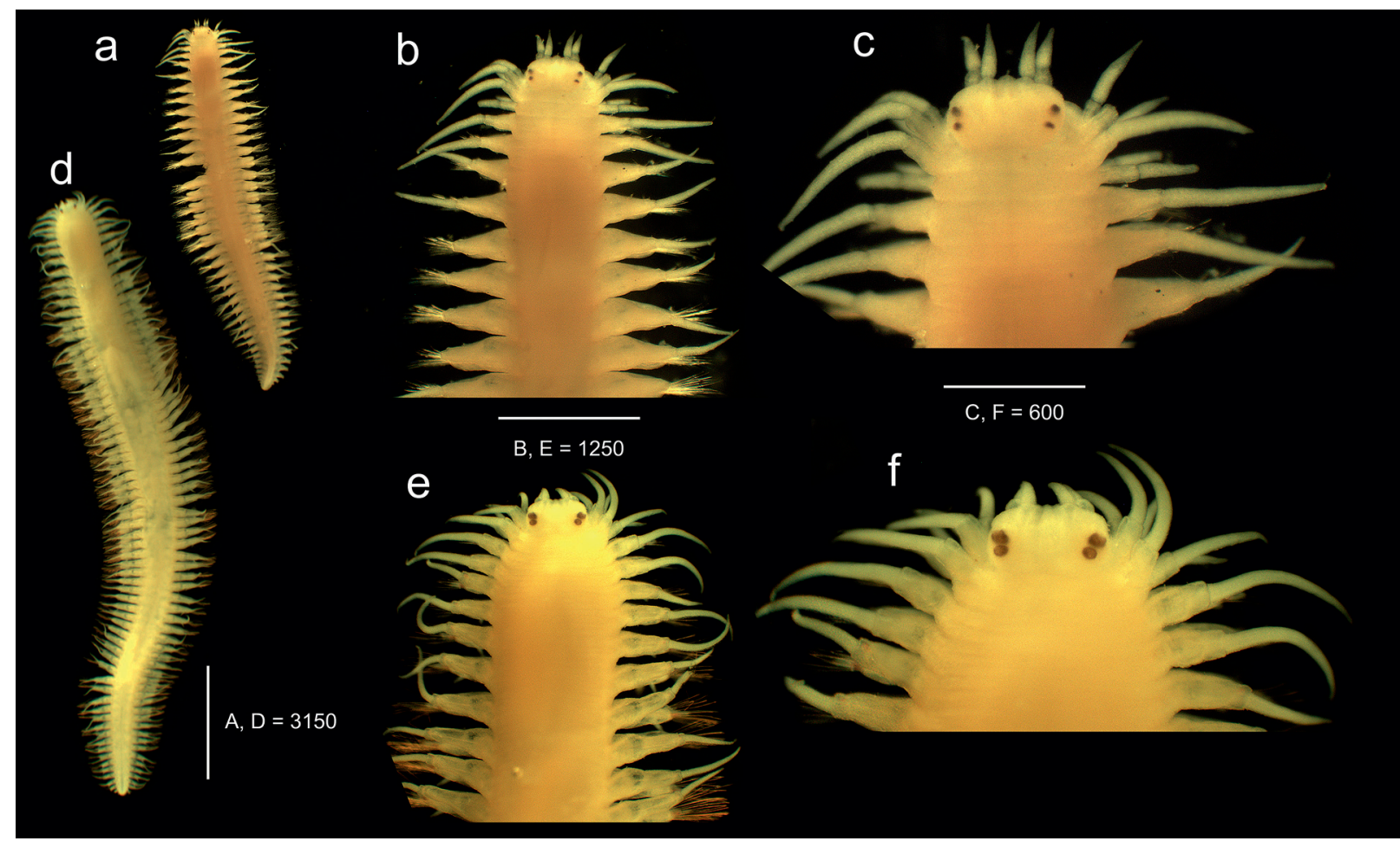

Fig. 8. Light microscopy micrographs of paratypes in dorsal view. Oxydromus okupa sp. nov. a. Whole worm. b. Anterior mid-body. c. Anterior end. Oxydromus humesi. d. Whole worm. e. Anterior mid-body. f. Anterior end. Scale bars are $\mu \mathrm{m}$.

pairs of small reddish-brown eyes (dark brown when preserved), a median ridge, biarticulated palps and three smooth antennae inserted frontally; palpophores cylindrical, palpostyles flask-shaped, about twice the length of palpophores; median antenna very small, button like; lateral antennae conical, with tapering tips. Nuchal organs on lateroposterior prostomial margin.
Facial tubercle present. Lip pads absent. Proboscis with two smooth rings and a terminal ciliated one. Jaws absent. Segment 1 dorsally reduced. Parapodial lobes and chaetae absent on segments 1-3. Long and short dorsal cirrophores distinct, ventral ones often indistinct. Dorsal and ventral cirrostyles smooth, distally tapering, slightly alternating short and long, ventral cirri shorter 


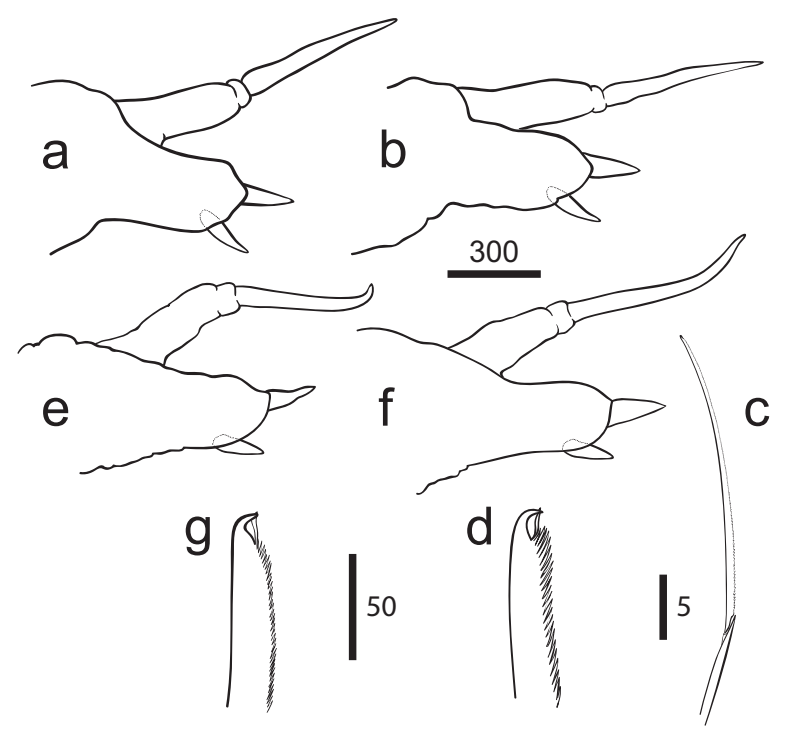

Fig. 9. Oxydromus okupa sp. nov. a. Chaetiger 10, posterior view. b. Chaetiger 30, posterior view. c. Typical articulated chaeta. d. Tip of articulated chaeta. Oxydromus humesi. e. Chaetiger 10, posterior view. f. Chaetiger 30, posterior view. g. Tip of articulated chaeta. Scale bar is $\mu \mathrm{m}$.

than dorsal, with blunt tip. Parapodia subbiramous from segment 4 onwards; notopodial lobe achaetous, half as long as neuropodial one, alternating elevated and non-elevated, with cirrophore on tip, with up to five aciculae; neuropodial lobes chaetigerous, elongated, subconical, with blunt tips, with long digitiform prechaetal lobe, rounded postchaetal lip, up to three aciculae and numerous compound neurochaetae, with heterogomph shafts, unidentate blades (middle ones much longer than dorsal and ventral) with curved, blunt tips, finely denticulate cutting edges, and a long subdistal spine reaching tip of curved end. One pair of pygidial cirri, similar to dorsal cirri. Pygidial papilla absent. Anus terminal.

Morphometric description. This description is based on the holotype (MNCN 16.01/17760); "long" and "short" refer to parapodia of chaetigers 10 and 15 , bearing long and short cirrostyles, respectively). Tables 3 and 6 summarizing population ranges and averages. Body $11.6 \mathrm{~mm}$ long, $2 \mathrm{~mm}$ wide at the level of chaetiger 10 , with 48 segments. Body width (without parapodia) ca. 0.35 as wide as with parapodia, ca. 5.8 as wide as body length. Ratio number of segments vs. body width (with parapodia) $=0.02$. Prostomium $287 \mu \mathrm{m}$ long and $499 \mu \mathrm{m}$ wide; lateral antenna $226 \mu \mathrm{m}$ long; palpostyles almost twice as long as palpophores, $150 \mu \mathrm{m}$ and 74 $\mu \mathrm{m}$ long, respectively. Lateral antennae (226 $\mu \mathrm{m}$ long), palpophores (74 $\mu \mathrm{m}$ long) and palpostyles $(159 \mu \mathrm{m}$ long) $0.8,0.3$ and 0.5 as long a prostomium length, respectively. Distance between anterior eyespots $386 \mu \mathrm{m}$; distance between posterior eyespots $356 \mu \mathrm{m}$; distance between anterior and posterior eyespots $61 \mu \mathrm{m}$. Distance between anterior eyespots ca. 1.09 as long as that between posterior ones. Distance between anterior and between posterior eyespots ca. 0.7 and 0.8 as long as prostomium width, respectively. Distance between anterior and posterior eyespots ca. 0.21 as long as prostomium length. Long and short dorsal lobes similar in size, ca. $210 \mu \mathrm{m}$ long, tips almost reaching those of ventral lobes. Long and short dorsal cirrophores 41 and 30 $\mu \mathrm{m}$ long, 0.14 and 0.2 as long a dorsal lobe. Long and short dorsal cirrostyles 530 and $512 \mu \mathrm{m}$ long, ca. 2.4, 2.5 as long as dorsal lobes, and 17.8 and 12.8 as long as cirrophores. Long and short posterior neurochaetal lobe similar in size, ca. $136 \mu \mathrm{m}$ long. Long and short ventral cirri 206 and $198 \mu \mathrm{m}$ long, ca. 1.5 as long as posterior neurochaetal lobes.

Remarks: Oxydromus okupa sp. nov. and the morphologically-similar $O$. humesi share a virtually identical general morphological description, which resulted in them being initially identified as the same species (Martin et al. 2015). There was a single chaetal type, compound ones with heterogomph unidentate blades, which were very similar in both species. The blade serration seemed to be longer in the new species than $O$. humesi, although this character is highly variable and depends on the observed chaetae so that we strongly suggest not relying on it to differentiate the two species. Specimens corrected for body size (as body width including parapodia) show significant quantitative differences in body measurements (Table 6). Among these differences, the new species has significantly fewer segments and a narrower body width (without parapodia). The head is almost $4 \%$ wider, and the cephalic appendages are significantly longer in O. okupa sp. nov., with the latter including dimensions of palpophores (12\% longer), palpostyles (14\% longer), lateral antennae (19\% longer) and distances between eyes (particularly between the anterior and posterior pairs). Some parapodial measurements are also significantly longer (6 to $9.6 \%$ long), while the dorsal lobe is the only character being shorter in O. okupa sp. nov. (8.5\% and $13 \%$ shorter in parapodia bearing long and short cirrostyles, respectively). Moreover, dorsal and ventral lobes are similar in length, with the tip of the former reaching the tip of the latter in O. okupa sp. nov., while the dorsal 
lobe is much shorter than the ventral one in O. humesi. Oxydromus okupa sp. nov. differs from $O$. humesi in body measurement proportions (Table 8). Accordingly, O. okupa sp. nov. has the body width measured without parapodia proportionally narrower with respect to the body width measured with parapodia, and it has also fewer segments. The new species also has the cephalic appendages proportionally longer with respect to prostomium length, particularly in the case of lateral antennae (more than $16 \%$ longer), and the distance between anterior and posterior eye pairs is also significantly longer, too. All ratios concerning parapodial measurements are also higher for O. okupa sp. nov., with the most marked differences being at the level of the dorsal cirrostyle vs. the corresponding dorsal lobe (15-22\%) and the cirrophore $(9-13.5 \%)$. Serration near blade tip as long as blade width.
Etymology: The specific epithet "okupa" refers to the Okupas (i.e., the Spanish squatters), a movement that emerged in the 80 s as a response to the ever-increasing difficulty of housing opportunities. Okupation means squatting in empty buildings for the own use of the okupas, which implies self-organisation and alternative relationship mechanisms, in a parallel way as symbiotic polychaetes interact with their hosts and with the whole ecosystem.

Geographical distribution: Despite the wide distribution of S.plana in European waters (Santos et al., 2011), Oxydromus okupa sp. nov. is currently only known from the type locality, the intertidal of Río San Pedro saltmarshes, and the nearby subtidal environments of Cádiz Bay (southern Atlantic coast of the Iberian Peninsula). 